\title{
The Effect of Human Resource Management Practices in Enhancing Employee Performance in Catholic Institutions of Higher Learning in Kenya
}

\author{
Mercy Gacheri Munjuri \\ Department of Marketing and Management \\ The Catholic University of Eastern Africa \\ P.O Box 62157-00200, Nairobi. \\ Kenya \\ Tel: +254-722-641-535_E-mail: mgacheri@cuea.edu \\ URL: http://dx.doi.org/10.5430/ijba.v2n4p189
}

Received: July 11, $2011 \quad$ Accepted: August 18, $2011 \quad$ Published: November 21, 2011

doi:10.5430/ijba.v2n4p189

\begin{abstract}
This study focused on the effect that human resource management (HRM) practices have on employee performance. The study sought to establish the effect of training, performance-related pay, employee empowerment, job-design and job security on employee performance in catholic institutions of higher learning in Kenya. The research design used was descriptive survey research design. The target population was all the support staff of the institution. Stratified random sampling technique was used. Data was collected using questionnaires and analyzed using descriptive statistics such as frequencies and percentages. Correlation and regression analysis was done to establish the relationship between various HRM practices and employee performance. Data was presented in form of tables, charts and graphs.

Based on the findings, performance-related pay has the greatest impact on increasing employees' level of performance. Training and employee empowerment have also got an effect of increasing employees' level of performance. Job design and job security have got the least impact on performance.
\end{abstract}

Keyword(s): Training, Performance-Related Pay Employee Empowerment, Job-Design, Job Security, Employee Performance, Catholic Institutions of Higher Learning, Kenya.

\section{Introduction}

\subsection{Background of the Study}

This study focuses on the impact that progressive human resource management (HRM) practices have on improvement of organizational performance. The way an organization manages people can influence its performance. In particular HRM practices such as employee participation and empowerment, job redesign, team-based production systems, extensive employee training and performance-contingent incentive compensation are widely believed to improve the performance of organizations (Pfeffer, 1994).

Organizations can adopt various HRM practices to enhance employee skills as well as motivate them to work harder towards achieving the set targets.

Organizations can improve the quality of current employees by providing comprehensive training and development activities. Considerable evidence suggests that investments in training produce beneficial organizational outcomes (Bartel, 1994; Knoke \& Kalleberg, 1994). The effectiveness of skilled employees will be limited, however, if they are not motivated to perform their jobs. Organizations can implement merit pay or incentive compensation systems that provide rewards to employees for meeting specific goals. Incentive compensation and performance management systems enhance the performance of employees and organizations (Gerhart \& Milkovich, 1992). Performance management as a process explicitly recognizes that in today's globally competitive industrial environment, every employee's efforts must focus on helping the company to achieve its strategic goals (Dessler, 2008).

The notion behind individual performance-related pay is that employees will be motivated if they believe they will be rewarded for improving their contribution to the success of the enterprise. This view derives from many years of 
psychological thinking. For behaviorists such as B. F. Skinner, learning only takes place through external positive and negative reinforcement. The right behaviour could be encouraged through the use of rewards and praise and, to a lesser extent, discouraged through punishments. F. W. Taylor applied these theories in the workplace and advocated the use of piece rate payments as a means of controlling behaviour and orientating it to management requirements. In contrast to this employer-centred view, expectancy and goal theorists put the emphasis on cognition i.e. the thought processes employees go through that affect their performance in the workplace. They looked at the expectation of future reinforcement rather than past. Goal theorists pursued this argument by saying that future goals can be used to influence behaviour and motivation (Reily, 2005).

Implementing performance-related pay (PRP) is by no means a total solution for motivating employees and increasing productivity, as it is widely recognized that for most people money is not the most important aspect of a job. Opinions differ greatly between organizations over the effectiveness of PRP-many organizations have tried PRP, only to abandon it later. Whenever PRP is used, it should be in conjunction with other methods to improve employee performance (Chartered Management Institute, 2005).

Researchers have concluded that employee participation has at least a moderately positive affect on job satisfaction and productivity. Miller and Monge (1986) reported a positive correlation between participation and job satisfaction in studies conducted in organizational settings that incorporated measures of multiple-issue participation. A correlation between participation and productivity was revealed when they averaged the results of field studies lacking goal-setting interventions. Wagner and Gooding (1987), in studies that contrasted directive versus participative processes, found a correlation between participation and satisfaction when participants were asked to perform simple tasks. This is important because it helps support the suggestion that participation helps enrich simplified work. Smith and Brannick (1990) also speculate that participation causes greater job satisfaction because the employee feels more valued and trusted by management, and because the worker gains a better understanding of management difficulties by dealing with some of the same problems.

A large body of research provides evidence that the way jobs are designed impacts outcomes that are important to workers (e.g. job satisfaction) and to employers (e.g. productivity). Job design can be approached with one or more goals in mind. For instance, jobs can be designed in the interest of increasing production efficiency, minimizing physical strain, or with an eye on maximizing the extent to which they are motivating to the worker (Campion \& Thayer, 1985). Research on the job characteristics model has also found relations between employee perceptions of specific core characteristics inherent in the job's design (skill variety, task identity, task significance, autonomy, and feedback from the job itself) and employee intrinsic job motivation and satisfaction with the job itself. A job that possesses higher levels of these core characteristics is higher in motivating potential.

\subsection{Problem Statement}

Recruiting and selecting high potential employees doesn't guarantee that they will perform effectively. People who do not know what to do or how to do it cannot perform effectively even if they want to. Therefore there is need for organizations to train employees in order to ensure that they know what to do, and how to do it.

Training is an expensive venture and organizations need some assurance of return on investment on training, in the form of enhanced productivity. The question is, does training increase performance? The total reward concept emphasizes on combining intrinsic and extrinsic motivators to get a complete package. Organizations use performance-related pay as an extrinsic motivator to recognize and reward those employees that meet the set performance targets. Intrinsic motivation is provided when people feel that the work they do is intrinsically interesting, challenging and important and involves the exercise of responsibility, autonomy or freedom to act, and opportunities for advancement and growth.

Employee empowerment is also believed to be a motivator since employee involvement in decision-making makes them feel valued. This also cultivates a sense of commitment to the organization. Since the business environment is becoming more and more competitive, organizations are looking out for employees that can perform, hence the issue of performance contracts. Job security is not guaranteed, since one's stay in the organization depends on one's performance. Do all these HRM practices i.e. training, performance-related pay, empowerment, job-design and job security increase employee performance and productivity?

This study therefore aimed at determining the effect of Human Resource Management practices in enhancing employee performance in catholic institutions of higher learning in Kenya.

\subsection{Research Objectives}

1. To determine the status of Human Resource Management (HRM) practices in Catholic institutions of Higher learning in Kenya 
2. To determine the effect of HRM practices on employee performance

3. To establish the extent to which performance would improve following the implementation of various HRM practices

4. To establish the relationship between the perceived effect of HRM practices and employee performance

\subsection{Importance of the Study}

The study will provide insight to organizations on the effect the various HRM practices have on employee performance, hence enabling them to take the necessary action in order to improve overall organizational performance.

\subsection{Conceptual Framework}

$<$ Figure 1 about here $>$

\section{Literature Review}

\subsection{Training}

\subsubsection{The Concept of Training}

Training refers to the methods used to give new or present employees the skills they need to perform their jobs (Dessler, 2008).

Training refers to improving competencies needed today or very soon (Jackson \& Schuler, 2000).

Training is the planned and systematic modification of behaviour through learning events, programmes and instruction which enable individuals to achieve the levels of knowledge, skill and competence needed to carry out their work effectively (Armstrong, 2006).

According to Dessler (2008) the training process starts with determining what training is required. Analyzing training needs depends on whether you are training new or current employees. The main task in analyzing new employees' training needs is to determine what the job entails and to break it down into subtasks, each of which you then teach to the new employee. Analyzing current employees' training needs can be done through task analysis and performance analysis. Determining training needs is done at three levels; organizational needs analysis which involves examination of short and long-term objectives of the organization and the trends that are likely to affect these objectives. It can include a human resource analysis, analyses of efficiency indexes, and an assessment of the organizational climate.

Job needs analysis involves examining jobs through job analysis. For existing jobs, information on the tasks to be performed, the skills necessary to perform those tasks, and the minimum acceptable standards are gathered. Person needs analysis identifies gaps between a person's current capabilities and those identified as necessary or desirable (Dessler, 2008).

Second, designing a training program involves setting training objectives and choosing the training methods. Training methods can be divided into on-the-job training and off-the-job training methods. On the job training methods include coaching, mentoring, job rotation. Off-the-job methods include formal courses, lecture, discussion, role playing and case study (Armstrong, 2006).

Third, actual implementation of the training is done. It is important to increase learning during training. This can be done by providing for active participation; increasing self efficacy; matching training techniques to trainees' self efficacy; providing opportunities for enactive mastery; ensuring specific, timely, diagnostic, and practical feedback; and providing opportunities for trainees to practice new behaviours (Jackson \& Schuler, 2000).

Fourthly, training should be evaluated to check on its effectiveness. Training programs can be evaluated at four stages as suggested by Kirk Patrick in Desimone, Werner and Harris (2002):

i. Reaction (level 1)

Did the trainees like the program and feel it was useful? At this level, the focus is on the trainees' perceptions about the program and its effectiveness. This is useful information. Positive reactions to a training program may make it easier to encourage employees to attend future programs. But if trainees did not like the program or think they didn't learn anything (even if they did), they may be reluctant to use the skills or knowledge obtained in the program. The main limitation of evaluating HRD programs at the reaction level is that this information cannot indicate whether the program met its objectives beyond ensuring participant satisfaction

ii. Learning (level 2) 
Did the trainees learn what the HRD objectives said they should learn? This is an important criterion that many in the organization would expect an effective HRD program to satisfy. Measuring whether someone has learned something in training may involve a question or test, clearly a different method from assessing the participants' reaction to the program

iii. Job behaviour (level 3)

Does the trainee use what was learned in training back on the job? This is also a critical measure of training success. We all know coworkers who have learned how to do something but choose not to. If learning does not transfer to the job, the training effort cannot have an impact on the employee's or organization's effectiveness. Measuring whether training has transferred to the job requires observation of the trainee's on-the-job behaviour or viewing organizational records (e.g, reduced customer complaints, a reduction in scrap rate etc).

iv. Results (level 4)

Has the training or HRD effort improved the organization's effectiveness? Is the organization more efficient, more profitable, or better able to serve its clients or customers as a result of the training program? Meeting this criterion is considered to be the bottom line as far as most managers are concerned. It is also the most challenging level to assess, given that many things beyond employee performance can affect organizational performance. Typically at this level, economic and operating data (such as sales or waste) are collected and analyzed.

\subsubsection{Benefits of Training}

According to Armstrong (2006) effective training can minimize learning costs; improve individual, team and corporate performance in terms of output, quality, speed and overall productivity; improve operational flexibility by extending the range of skills possessed by employees (multi-skilling); attract high quality employees by offering them learning and development opportunities, increasing their levels of competence and enhancing their skills, thus enabling them to obtain more job satisfaction to gain higher rewards and to progress within the organization; help to manage change by increasing understanding of the reasons for change and providing people with the knowledge and skills they need to adjust to new situations; help to develop a positive culture in the organization, one that is oriented towards performance improvement; provide higher levels of service to customers.

2.2 Performance Related Pay (PRP)

Agreed $\longrightarrow$ performance $\longrightarrow$ performance $\longrightarrow$ rating

Outcomes/targets measures

Formula $\longrightarrow$ performance pay

Pay increases are related to the achievement of agreed results defined as targets or outcomes. Scope is provided for consolidated pay progression within pay brackets attached to grades or levels in a graded or career family structure, or zones in a broad banded structure. Alternatively, high levels of performance or special achievements may be rewarded by cash bonuses, which are not consolidated and have to be re-earned. Individuals may be eligible for such bonuses when they are assessed as being fully competent, having completely progressed along their learning curve. The rate of pay for someone who reaches the required level of competence can be aligned to market rates according to the organization's pay policy. The rates and limits of progression through the pay brackets are typically but not inevitably determined by performance ratings, which are often made at the time of the performance management review but may be made separately in a special pay review. Some organizations do not base PRP increases on formal ratings and instead rely on a general assessment of how much the pay of individuals should increase by reference to performance, potential, the pay, levels of their peers and their market worth (Armstrong \& Stephens, 2006).

According to Dessler (2008) merit pay or a merit raise is any salary increase the firm awards to an individual performance. It is different from a bonus in that it usually becomes part of the employee's base salary, whereas a bonus is a one time payment. Advocates argue that only pay or other rewards tied directly to performance can motivate improved performance. They contend that the effect of awarding pay raises across the board (without regard to individual merit) may actually detract from performance, by showing employees they will be rewarded regardless of how they perform.

\subsubsection{Performance Management}

According to Dessler (2008), performance management is a process that consolidates goal setting, performance appraisal, and development into a single, common system, the aim of which is to ensure that the employee's performance is supporting the company's strategic aims. 
Performance management is a strategic and integrated process which delivers sustained success to organizations by improving the performance of the people who work in them and by developing the capabilities of individual contributors and teams (Armstrong \& Stephens, 2006). Performance Management includes the practices through which the manager defines the employee's goals and work, develops the employee's capabilities, and evaluates and rewards the person's effort all within the framework of how the employee's performance should be contributing to achieving the company's goals. When properly designed, performance management therefore never just entails meeting with a subordinate once or twice a year to review their performance. It means setting goals that make sense in terms of the company's strategic needs. It means daily or weekly interactions to ensure continuous improvement in the employee's capacity and performance. Performance management as a process also explicitly recognizes that in today's globally competitive industrial environment, every employee's efforts must focus on helping the company to achieve its strategic goals. In that regard, adopting an integrated performance management approach to guiding, developing, and appraising employees also aids the employer's continuous improvement efforts. Continuous improvement refers to a management philosophy that requires employers to continuously set and relentlessly meet ever-higher quality, cost, delivery, and availability goals. Continuous improvement means eradicating wastes wherever they are, including the seven wastes of overproduction, defective products, and unnecessary downtime, transportation, processing costs, motion and inventory. Central to this philosophy is the idea that each employee must continuously improve his or her own personal performance, from one appraisal period to the next.

\subsubsection{Performance Appraisal}

Performance appraisal means evaluating an employee's current and/or past performance relative to his or her performance standards (Dessler, 2008). The performance appraisal process contains three steps: define the job, appraise performance, and provide feedback. Defining the job means making sure that the supervisor and the subordinate agree on his or her duties and job standards. Appraising performance means comparing the subordinate's actual performance to the standards that have been set. Third, performance appraisal usually requires one or more feedback sessions. Here the supervisor and subordinate discuss the subordinate's performance and progress and make plans for any development required (Dessler, 2008).

\subsection{Employee Empowerment and Participation}

According to Collins (1995) participation and empowerment are natural corollaries. Effective participation is born of a feeling of political efficacy or, if you will, a sense of empowerment. Thus, if workers are to participate fully within their organizations, empowerment will be required.

According to Smith (1997) to empower is to give power, to open up, to release potential of people. In these terms it can be viewed as a commonsense activity. Typically, it embraces job involvement, job enrichment, participation in various forms, including suggestions schemes. Essentially the main thrust of empowerment is through having greater autonomy over 'how' jobs are done, carrying with it immense potential for improving productivity.

For empowerment to flourish, people need to feel that they are valued. They need to be given frequent and constructive feedback on their performance. They also need to feel that they are genuinely contributing to customer satisfaction and business objectives and adding value to products, to services and to the bottom line.Once established, empowerment can result in continuing improvement with people being motivated to review and improve how they do what they do. empowerment has tremendous scope for managers to get the best out of their people, to release their potential, to help them grow and develop. Organizations cannot develop unless their people are developing (Smith, 1997).

\subsubsection{The Potential Benefits of Empowerment}

Greasley, Bryman, Dainty, Price, Soetanto and King (2005) noted that the espoused benefits of empowerment can be broadly divided into two areas: benefits for the organisation; and benefits for the individual. Much of the research into empowerment has focused on organisational benefits assuming these are the driving force behind attempts to engender empowered working (Cunningham et al., 1996).

Global competition and a changing business environment have instigated organisational change in response to increased pressures to improve efficiency and performance (Lawler et al., 1992). Specifically organisations have sought improvements in cost control, flexibility, quality improvement (Psoinos and Smithson, 2002). It has been argued that empowered organisations have demonstrated improvements in various economic performance areas (Applebaum et al., 1999). However, measurement of the economic benefits of empowerment specifically may be difficult as often it is introduced as part of a broader initiative such as BPR and TQM (Psoinos and Smithson, 2002).

While the primary motive of empowerment is usually to improve the economic performance of the organisation, benefits to the individual employee have also been identified. Nykodym et al. (1994) found that employees who consider 
themselves empowered have reduced conflict and ambiguity in their role, as they are able to control (to a certain extent) their own environment. They suggested that this reduces emotional strain on the employee. On a similar theme, it was reported that empowered employees have a greater sense of job satisfaction, motivation and organisational loyalty (Mullins and Peacock, 1991), as they feel more involved in the achievement of the organisational goals.

\subsubsection{Barriers to Empowerment}

Managers are faced with many difficulties when attempting to empower employees and these may prevent a business from becoming an empowering organisation. First, there is often resistance to the change both from managers/leaders and from employees themselves. It is often assumed that employees will buy into empowerment, as the benefits are "obvious". However, this has been disputed by Johnson (1994) who claims that previously disempowered employees may resist empowerment, as they fear the increased levels of responsibility and accountability. Further, employees may consider empowerment to be just empty rhetoric and yet another management attempt to exploit them. Adler (1993) demonstrated that empowerment is linked to downsizing as frequently these two activities occurred simultaneously. Therefore, it is hardly surprising that employees may be reluctant and suspicious of management schemes.

Managers/leaders may also be resistant to empowerment for this may be perceived as relinquishing power. They may view the reduction of their power as a threat (Denham et al., 1997), particularly as they too fear job loss or loss of status as the organisational structures become flatter during the downsizing process. They may also very in their inclination to introduce empowerment in spite of its being a component of organisational policy.

\subsubsection{Stages of Empowerment}

There are five distinct levels or stages of autonomy and empowerment in which a team and its manager operate.

Stage one

At stage one, the manager makes the decisions and informs the team. This may seem basic and obvious but, all too often, managers operate on a pre-stage one level - they make their decisions and do not bother to inform the team.

Stage two

Here the manager asks the team for suggestions, makes the decisions based on those suggestions and informs the team.

Stage three

The manager and the team discuss the situation at length, management asks for proposals and input from the team (which may or may not be adopted), makes the decisions and informs the team.

\section{Stage four}

This stage continues building on this relationship and, at this point, the decisions are made cooperatively between management and the team.

Stage five

In stage five, the manager delegates the decision making to the team. The team operates completely autonomously, making crucial decisions of which they may or may not, at their discretion, inform management (Pastor, 1996)

\subsection{Job Design}

Job design is the process of defining the way work will be performed and the tasks that will be required in a given job (Noe, Hollenbeck, Gerhart \& Wright, 2007). The way that jobs are designed should have an important tie to the strategy of an organization because the strategy requires either new and different tasks or different ways of performing the same tasks. In addition, because many strategies entail the introduction of new technologies, this impacts the way that work is performed. In general, jobs can vary from having a narrow range of tasks (most of which are simplified and require a limited range of skills) to having a broad array of complex tasks requiring multiple skills. In the past, the narrow design of jobs has been used to increase efficiency, while the broad design of jobs has been associated with efforts to increase innovation. However, with the advent of total quality management methods and a variety of employee involvement programs such as quality circles, many jobs are moving toward the broader end of the spectrum (Noe et al., 2007). According to Garg and Rastogi (2006) Job design and its approaches are usually considered to have begun with scientific management in the year 1900. Pioneering scientific managers such as Taylor suggested that task design might be the most prominent element in scientific management.

\subsubsection{Approaches to Job Design}

Garg and Rastogi (2006) observed that the approaches to job design have been postulated in such a manner that they indirectly affect an employee's level of motivation. The approaches to job design have worked in different perspectives 
for various organizational developments. These approaches are: job engineering (J.Eng.); job enrichment (JE); quality of work life (QWL); social information processing approach (SIPA) and job characteristics.

Job enrichment (JE):

The technique entails enriching the job, which refers to the inclusion of greater variety of work content, requiring a higher level of knowledge and skill, giving workers autonomy and responsibility in terms of planning, directing, and controlling their own performance, and providing the opportunity for personal growth and meaningful work experience.

Job engineering (JEng):

The scientific management approach evolved into what is now generally called job engineering. It is closely associated with cybernation and sophisticated computer applications, computer assisted design (CAD), and human-machine interactions. In fact, it has been the dominant aspect of job design analysis.

Quality of work life (QWL) and socio-technical design:

The overriding purpose of quality of work life is to change the climate at work so that the human-technological-organizational interface leads to a better quality of work life.

Social information processing approach (SIPA):

The social information processing approach to job design suggests that individual needs, task perceptions, and reactions are socially constructed realities. The process includes choice, revocability, publicness, explicitness, social norms and expectations, and external priming, which combine with social information (from others and the organizational environment) and influence the jobholders' perceptions, attitudes and behaviors.

The job characteristics approach to job design:

To meet the limitations of Herzberg's approach to job enrichment (which he prefers to call orthodox job enrichment (OJE), Hackman and Oldham (1976) developed the most widely recognized model of job characteristics. Basically, this model recognized certain job characteristics that contribute to certain psychological states and that the strength of employees' need for growth has an important moderating effect. The core job characteristics include;

- Skill variety. This refers to the extent to which the job requires the employee to draw from a number of different skills and abilities as well as upon a range of knowledge.

- Task variety. This refers to whether the job has an identifiable beginning and end or how complete a module of work the employee performs.

- Task significance. This involves the importance of the task. It involves both internal significance (i.e. how important the task is to the organization) and external significance (i.e. how proud employees are to tell their relatives, friends, and neighbours what they do and where they work).

- Autonomy. This refers to job independence. How much freedom and control employees have to perform their job, for example, schedule their work, make decisions or determine the means to accomplish the objectives.

- Feedback. This refers to objective information about progress and performance that can come from the job itself, from supervisors or from any other information system.

\section{Research methodology}

\subsection{Research Design}

This was a descriptive study aimed at gaining in depth understanding of the effect that various Human Resource Management practices have on individual employee performance.

\subsection{Population}

The population of interest was all the support staff of the institution that totaled to 176 employees.

\subsection{Sample and Sampling Techniques}

Stratified random sampling technique was used, where the support staff was divided into strata based on departments in which they worked, and thereafter respondents were selected randomly from the various departments that provide support services to the institution as shown below. 


$\begin{array}{lcc}\text { Total no. of employees } & \text { Sample } \\ \text { Library } & 20 & 10 \\ \text { ICT } & 30 & 15 \\ \text { Registrar } & 20 & 10 \\ \text { Secretaries } & 50 & 25 \\ \text { Accounts } & 30 & 15 \\ \text { Personnel } & 12 & 6 \\ \text { Research } & 14 & 7 \\ \text { Total } & \mathbf{1 7 6} & \mathbf{8 8}\end{array}$

\subsection{Data Collection Instruments}

Data was collected using questionnaires. Questionnaires were administered on a drop-and-pick up later basis.

\subsection{Data Analysis and Presentation}

Data was analyzed using descriptive statistics such as frequencies and percentages. Correlation and regression analysis was done to establish the relationship between various HRM practices and employee performance. Data was presented in form of tables, charts and graphs.

\subsection{Regression Model}

Let the dependent variable, performance be denoted by $\mathrm{z}$

Let the independent variables job design, empowerment, job security, training and performance-related pay be denoted by $\mathrm{x}_{1}, \mathrm{x}_{2}, \mathrm{x}_{3}, \mathrm{x}_{4}$ and $\mathrm{x}_{5}$ respectively.

$\mathrm{z}=\mathrm{f}$ (job design, empowerment, job security, training and performance-related pay) $=\mathrm{f}\left(\mathrm{x}_{1}, \mathrm{x}_{2}, \mathrm{x}_{3}, \mathrm{x}_{4,} \mathrm{x}_{5}\right)$

$\mathrm{z}=\mathrm{f}\left(\mathrm{x}_{1}, \mathrm{x}_{2}, \mathrm{x}_{3}, \mathrm{x}_{4}, \mathrm{x} 5\right)$

Also let

$\mathrm{Z}=\mathrm{a}+\mathrm{b}_{1} \mathrm{x}_{1}+\mathrm{b}_{2} \mathrm{x}_{2}+\mathrm{b}_{3} \mathrm{x}_{3}+\mathrm{b}_{4} \mathrm{x}_{4}+\mathrm{b}_{5} \mathrm{x}_{5}+\mathrm{e}$

Where $\mathrm{a}=$ parameter of regression model

$\mathrm{b}=$ parameter of regression model

$\mathrm{x}=$ independent variables

$\mathrm{e}=$ standard error

\section{Data Analysis and Findings}

\subsection{Response Rate}

Out of the 88 questionnaires that were issued, only 33 of them were collected. The response rate therefore was $37.5 \%$.

\subsection{Respondent's Data}

Majority of the respondents were male (57.6\%) while $42.4 \%$ were female as shown in table 1.

Table 2 shows that $48.5 \%$ of the respondents were degree holders, $33.3 \%$ had diplomas and certificates while $9.1 \%$ had masters degree and o-level education.

Majority of the respondents (69.7\%) had served in the organization for a period of $0-5$ years, $24.2 \%$ for a period of $5-10$ years and $6.1 \%$ for a period of $10-15$ years.

All the respondents were middle level staff ranging between job grade M2 to M10.

\subsection{Responses on Training}

$68.8 \%$ of the respondents attended training, $28.1 \%$ not attend training, whereas $3.1 \%$ did not give any response.

On the type of training attended, $56.3 \%$ of the respondents attended continuous development training, $40.6 \%$ attended job-related training, whereas for $3.1 \%$, the training was job related, as depicted in table 5 .

Table 6 shows that for majority of the respondents (45.5\%) the course was paid for by their employer, $15.2 \%$ were self-sponsored and the remaining $39.4 \%$ shared the costs partially with the employer. 
The duration of the course lasted 0-4 weeks (28.1\%), 4-8 weeks (15.6\%), over 2 months 53.1\% and for 3.1\% of the respondents, the course lasted for 3 years, 1 year, $1 \frac{1 / 2}{2}$ years and 2 years.

Table 8 shows that majority of the respondents (45.5\%) felt that the training was job related whereas $15.2 \%$ said that the training was not job related.39.4\% did not respond.

$45.5 \%$ of the respondents were not consulted before the training, $15.2 \%$ were consulted and 39.4\% did not respond.

As shown in table $10,48.5 \%$ of the respondents found the training useful in helping them perform their tasks better while $12.1 \%$ did not.39.4\% did not respond.

Table 11 shows that $36.4 \%$ of the respondents noticed a difference in the feedback given to them by their supervisor before and after the training, while $21.2 \%$ did not notice any difference. $42.4 \%$ did not respond.

For $36.4 \%$ of the respondents, the feedback indicated an improvement in performance, while for $21.2 \%$ it did not indicate any improvement in performance. $42.4 \%$ did not respond.

\subsection{Responses on Performance-Related Pay}

The basis of rewards in the organization according to the respondents is performance (23.3\%), competence and skills (16.7) \% and length of service (30\%). Other basis include any additional skills one acquires which accounts for $13.3 \%$.

The indication is that the organization likes rewarding long-serving employees for the loyalty portrayed.

Majority of respondents (75.8\%) felt that salary increments are effected annually, 3\% said it is based on ones performance, while $21.2 \%$ felt that it is based on additional skills acquired.

$66.7 \%$ of the respondents do not perceive fairness in the way salary increments are effected, while $33.3 \%$ perceive fairness.

Majority of respondents (57.6\%) said that the supervisor clearly defines the performance targets, while $39.4 \%$ felt otherwise. $3 \%$ did not respond.

$65.6 \%$ of respondents felt that the performance targets were achievable, while $34.4 \%$ felt that they were not.

Majority of respondents (56.3\%) said that they received feedback from their supervisors on how well or poorly they had performed their tasks, 34.4\% said they did not receive any feedback.9.3\% did not respond.

Feedback is given every 1 month (26.9\%), every 3 months (30.8\%), every 6 months (3.8\%), and annually (38.5\%). The indication is that the normal practice is providing feedback annually and quarterly.

As shown in Table 20, majority of respondents $(71.9 \%)$ did not receive any financial rewards or salary increase following achievement of the set targets, while 25\% did receive. 3.1\% did not respond.

Those who received financial rewards, $63.3 \%$ did not value the rewards while $33.3 \%$ valued the rewards. $3.3 \%$ did not respond.

$50 \%$ of the respondents said that the rewards motivated them to improve their performance, while $42.9 \%$ said that rewards did not motivate them. $7.1 \%$ did not respond, as shown in table 22 below.

Majority of the respondent (90.9\%) felt that their performance affected the performance of the entire organization, while 9.1\% felt otherwise.

From those who felt that their performance affected that of the entire organization, $81.8 \%$ said that the effect was positive while $6.1 \%$ said the effect was negative $12.1 \%$ did not respond.

\subsection{Responses on Employee Empowerment, Job Design and Job Security}

The respondents said that the following Human Resource Management practices would improve their performance to a certain extent as follows;

Being allowed to exercise control over their work- to a large extent (90.9\%); exercising initiative and creativity in their work -to a large extent (87.9\%); challenging tasks- to a large extent (63.6\%) and to a moderate extent (33.3\%); deciding how to go about ones tasks - to a large extent (63.6\%) and to a moderate and very large extent (18.2\%); opportunity to make decisions that one can handle- to a very large extent (57.6\%), to a large extent (36.4\%) and to a moderate extent (6.1\%); ones input being sought in managerial decisions- to a very large extent (81.8\%) and to a large extent (15.2\%); being delegated to tasks that one can handle- to a very large extent (30.3\%), to a large extent (42.4\%) and to a moderate extent (27.3\%); assurance of job security as long as one can perform - to a very large extent (93.3\%), to a large and moderate extent (3\%); being equipped with skills required by ones job- to a very large extent (100\%); 
Setting of achievable targets- to a very large extent (100\%); employees input in setting of targets - to a very large extent (100\%); fair evaluation of performance- to a very large extent (93.9\%) and to a large extent (6.1\%); feedback on performance- to a large extent (72.7\%) and to a very large extent $27.3 \%$; salary increase on achievement of set targets to a very large extent (97\%); bonuses and incentives on achievement of targets- to a very large extent (97\%); fair administration of rewards- to a very large extent (93.9\%).

On correlation analysis, the following results were obtained;

The relationship between being allowed to exercise control over one's work and opportunity to make decisions that one can handle is 0.48 at $99 \%$ significance level. This shows a positive relationship that is not very strong.

The relationship between being allowed to exercise control over ones work and assurance of job security is 0.38 at $95 \%$ significance level. This is a weak positive relationship.

The relationship between challenging tasks and deciding how to go about ones tasks is 0.55 at $99 \%$ significance level, showing a fairly strong positive relationship.

The relationship between challenging tasks and opportunity to make decisions that one can handle is 0.52 at $99 \%$ significance level showing a fairly strong positive relationship.

The relationship between challenging tasks and assurance of job security is 0.41 at $95 \%$ significance level showing a positive relationship that is not strong.

The relationship between challenging tasks and fair evaluation of performance is 0.51 at $99 \%$ significance level, which shows a fairly strong positive relationship.

The relationship between challenging tasks and bonuses and incentives on achievement of targets is 0.52 at $99 \%$ level of significance showing a fairly strong positive relationship.

The relationship between opportunity to make decisions that one can handle and job security is 6.0 at $99 \%$ significance level, showing a fairly strong positive relationship.

The relationship between ones input being sought in managerial decisions and delegation of tasks is -0.57 , at $99 \%$ significance level showing a fairly strong negative relationship.

The relationship between job security and bonuses and incentives on achievement of targets is 0.89 at $99 \%$ significance level, showing a very strong positive, relationship.

The relationship between job security and fair evaluation of performance is 0.61 at $99 \%$ significance level, indicating a fairly strong positive relationship.

The relationship between fair evaluation of performance and bonuses and incentives on achievement of targets is 0.7 at 99\% significance level, indicating a strong positive relationship.

The relationship between fair administration of rewards and feedback on performance is

-0.42 at $95 \%$ significance level showing a weak negative relationship.

\subsection{Regression Model}

Let the dependent variable, performance be denoted by $\mathrm{z}$

Let the independent variables job design, empowerment, job security, training and performance-related pay be denoted by $x_{1}, x_{2}, x_{3}, x_{4}$ and $x_{5}$ respectively.

$\mathrm{z}=\mathrm{f}$ (job design, empowerment, job security, training and performance-related pay) $=\mathrm{f}\left(\mathrm{x}_{1}, \mathrm{x}_{2}, \mathrm{x}_{3}, \mathrm{x}_{4}, \mathrm{x}_{5}\right)$

$\mathrm{z}=\mathrm{f}\left(\mathrm{x}_{1}, \mathrm{x}_{2}, \mathrm{x}_{3}, \mathrm{x}_{\left.4, x_{5}\right)}\right.$

Also let

$\mathrm{Z}=\mathrm{a}+\mathrm{b}_{1} \mathrm{x}_{1}+\mathrm{b}_{2} \mathrm{x}_{2}+\mathrm{b}_{3} \mathrm{x}_{3}+\mathrm{b}_{4} \mathrm{x}_{4}+\mathrm{b}_{5} \mathrm{x}_{5}+\mathrm{e}$

Where $\mathrm{a}=$ parameter of regression model

$\mathrm{b}=$ coefficients

$\mathrm{x}=$ independent variables

$\mathrm{e}=$ standard error

a Predictors: (Constant), Performance-related pay , Empowerment , Job design, Job Security , Training

b Dependent Variable: Performance 
Total variation $=$ total $=\sum(y-\bar{y})^{2}=43.469$

Error of variation $=$ residual $=\mathrm{SSE}=\sum(y-y 1)^{2}=12.046$

Regression variation $=\mathrm{SSR}=\mathrm{SS}$ total $\mathrm{SSE}=43.469-12.046=31.423$

The regression equation is:

Performance $=0.530-0.126 \mathrm{x}_{1}+0.060 \mathrm{x}_{2}-0.058 \mathrm{x}_{3}+0.290 \mathrm{x}_{4}+0.611 \mathrm{x}_{5}+\mathrm{e}$

The variable "job design" shows an inverse relationship. This implies that as the level of job design increases, the level of performance decreases. Therefore, the negative sign for this coefficient is logical. For each additional level of control over one's work, there will there will be a decrease of one's level of performance by 12.6 percent, regardless of the other remaining four variables i.e. empowerment, job security , training and performance related pay

Empowerment has a direct relationship i.e. the more the level of empowerment, the higher the level of performance of the employees and vice versa. This means that for each additional unit of empowerment, there is a $6 \%$ increase in performance level, regardless of the other remaining four, variables i.e. job design, job security, training and performance -related pay.

The variable "job security" also has an inverse relationship. The more the level of job security, the less the level of performance. This means that for each additional unit of job security, there is a $5.8 \%$ decrease in performance level regardless of the other variables i.e. job design, empowerment, training and performance-related pay.

Training has also a direct relationship. This implies that for each additional unit of training, there is $29 \%$ increase in the level of performance. This effect occurs regardless of the other remaining variables.

The variable "performance-related pay "does have a direct relationship. This means as the performance-related pay increases so does the level of performance. For each additional unit of performance related pay, we expect the level of performance to increase by $61.1 \%$.

\subsection{Content Analysis}

Some of the obstacles employees felt hindered achievement of performance targets were lack of motivation, lack of freedom to exercise one's ability; lack of clear-cut job descriptions; lack of recognition, skewed promotions and salary increments, poor communication between employees and supervisors; lack of working tools and delays from other departments where output of one is input of another.

Some of the suggestions cited on how the organization can improve performance of employees were; giving rewards on achievement of targets, exercise fairness in all practices, implementation of performance contracts, effective communication, support employees training, provide career advancement opportunities, providing adequate working tools, clear policies on promotion and defining one's roles through clear job descriptions.

\section{Summary, Conclusion and Recommendations}

\subsection{Summary of Findings}

The first objective was to determine the status of various Human Resource Management practices in the institution..

The study revealed that majority of the middle-level employees were provided with training opportunities which in most cases the courses were paid for by the employer. However majority of the employees did not receive any financial rewards, after achievement of the set targets, meaning that there is no performance-related pay in the organization. The level of empowerment was moderate because employees were allowed to exercise minimal control over their work. Tasks performed by employees were not very challenging, and job security was not guaranteed since terms of employment were contract-based.

The second objective was to determine the effect of various Human Resource Management practices on employee performance.

For the small proportion of employees who claimed to have received financial rewards upon achievement of the set targets, half of them felt that the rewards motivated them to improve their performance. Quite a number of employees were provided with training opportunities, and they claimed that as a result of this, they were able to perform their tasks better. They also noticed an improvement in the feedback provided to them by their supervisors. Employees were able to perform their tasks more efficiently whenever they were provided with an opportunity to make decisions that they could handle.

The third objective was to establish the extent to which performance would improve following the implementation of various Human Resource Management practices. 
The study revealed that performance would improve to a very large extent when employees are provided with an opportunity to make decisions that they can handle, deciding how to go about one's tasks, employees' input being sought in managerial decisions, being delegated to tasks that one can handle, job security as long as one can perform, being equipped with skills required by one's job, setting of achievable targets, employees' input in setting of targets, fair evaluation of performance, salary increase on achievement of set targets, bonuses and incentives on achievement of targets and fair administration of rewards.

The fourth objective was to establish the correlation between performance and the various Human Resource Management practices. The study revealed that there is a very strong positive relationship between job security and bonuses and incentives on achievement of targets; relationship between fair evaluation of performance and bonuses and incentives on achievement of targets.

There is a fairly strong relationship between challenging tasks and bonuses and incentives on achievement of targets; relationship between challenging tasks and fair evaluation of performance; relationship between opportunity to make decisions that one can handle and job security; relationship between job security and fair evaluation of performance; relationship between challenging tasks and deciding how to go about one's tasks; relationship between challenging tasks and opportunity to make decisions that one can handle. There is a fairly strong negative relationship between one's input being sought in managerial decisions and delegation of tasks, there is a weak negative relationship between fair administration of rewards and feedback on performance.

From the regression model, it is clear that performance-related pay has the greatest impact on increasing employees' level of performance since there is a direct positive relationship. Training and empowerment have also got an effect of increasing employees' level of performance which is evident from the direct positive relationship. Job design and job security have got the least impact on performance and they have an inverse relationship with performance.

\subsection{Conclusion}

The findings of the study point to the fact that majority of the middle-level employees were provided with training opportunities. However majority of the employees did not receive any financial rewards, after achievement of the set targets, the level of empowerment was moderate because employees were allowed to exercise minimal control over their work, and job security was not guaranteed since terms of employment were contract-based.

The findings also point to the fact that the small proportion of employees who claimed to have received financial rewards upon achievement of the set targets, felt that the rewards motivated them to improve their performance. Quite a number of employees were provided with training opportunities, and they claimed that as a result of this, they were able to perform their tasks better. Employees were able to perform their tasks more efficiently whenever they were provided with an opportunity to make decisions that they could handle.

The study revealed that performance would improve to a very large extent when employees are provided with an opportunity to make decisions that they can handle, deciding how to go about one's tasks, employees' input being sought in managerial decisions, being delegated to tasks that one can handle, job security as long as one can perform, being equipped with skills required by one's job, setting of achievable targets, employees' input in setting of targets, fair evaluation of performance, salary increase on achievement of set targets, bonuses and incentives on achievement of targets and fair administration of rewards.

The study also revealed that there is a very strong positive relationship between job security and bonuses and incentives on achievement of targets; relationship between fair evaluation of performance and bonuses and incentives on achievement of targets.

There is a fairly strong relationship between challenging tasks and bonuses and incentives on achievement of targets; relationship between challenging tasks and fair evaluation of performance; relationship between opportunity to make decisions that one can handle and job security; relationship between job security and fair evaluation of performance; relationship between challenging tasks and deciding how to go about one's tasks; relationship between challenging tasks and opportunity to make decisions that one can handle. There is a fairly strong negative relationship between one's input being sought in managerial decisions and delegation of tasks, there is a weak negative relationship between fair administration of rewards and feedback on performance.

Performance-related pay has the greatest impact on increasing employees' level of performance since there is a direct positive relationship. Training and empowerment have also got an effect of increasing employees' level of performance which is evident from the direct positive relationship. Job design and job security have got the least impact on performance and they have an inverse relationship with performance. 


\subsection{Recommendations}

Since it is clear from the findings that training opportunities enhance the performance of employees, such opportunities should be provided to all employees.

Performance-related pay is critical in enhancing performance, hence the organization should implement this to motivate those employees who achieve the set targets.

The financial rewards should also be valuable to employees.

The basis of rewards in the organization should be performance in order to enhance a performance culture in the organization.

Employee empowerment is a motivator and hence has got an effect of increasing performance. Organizations should therefore allow employees to make decisions regarding their work that they can handle, seek employees' input in managerial decisions as well as delegation of tasks.

In order to enhance performance, the organization should provide employees with job security and bonuses and incentives on achievement of targets since these Human Resource Management practices have a very strong positive correlation with employee performance. Other practices that have a positive impact on employee performance include, opportunity to make decisions that they can handle, allowing employees to decide on how to go about their tasks, seeking employees' input in managerial decisions, delegating to them tasks that they can handle, equipping them with skills required by their jobs, setting achievable targets and incorporating employees in target-setting, fair evaluation of performance, salary increase on achievement of the set targets, and fair administration of rewards.

\subsection{Suggestions for Further Research}

A similar study should be conducted, drawing respondents from all the universities in Kenya, to check whether similar practices prevail across the board.

A similar study should target the academic staff to check for any variations in responses.

\section{References}

Adler, P. (1993). Time and motion regained, Harvard Business Review, January/February, pp.97-108.

Armstrong, M., (2006). A Handbook of Human Resource Management Practice (10 ${ }^{\text {th }}$ edition), London \& Philadelphia, Kogan Page Ltd

Armstrong, M. \& Stephens, T. (2006). Employee Reward Management Practice, London and Philadelphia, Kogan Page Ltd

Applebaum, S.H., Hebert, D., Leroux, S. (1999). Empowerment: power, culture and leadership - a strategy or fad for the millennium?, Journal of Workplace Learning: Employee Counselling Today, Vol. 11 No.7, pp.233-54

Bartel A. P. (1994), Productivity savings from the implementation of employee training programs, Industrial Relations, Vol. 4, No. 4, pp 411-425. http://dx.doi.org/10.1111/j.1468-232X.1994.tb00349.x

Campion, M. A. \& Thayer, P. W. (1985). Development and field evaluation of an interdisciplinary measure of job design, Journal of Applied Psychology, 70, 29-43. http://dx.doi.org/10.1037/0021-9010.70.1.29

Chartered Management Institute (2005).

Collins, D. (1995). Rooting for Empowerment? Empowerment in Organizations Journal, Vol. 3, No. 2, pp. 25-33. http://dx.doi.org/10.1108/09684899510089301

Cunningham, I., Hyman, J., \& Baldry, J. (1996). Empowerment: the power to do what?, Industrial Relations Journal, Vol. 27 No.2, pp.143-54. http://dx.doi.org/10.1111/j.1468-2338.1996.tb00764.x

Denham, N., Ackers, P., \& Travers, C. (1997). Doing yourself out of a job? How middle managers cope with empowerment, Employee Relations, Vol. 19 No.2, pp.147-59. http://dx.doi.org/10.1108/01425459710171030

Desimone, W. (2002). Human resource Development. , USA, South Western

Dessler, G. (2008). Human Resource Management (11 ${ }^{\text {th }}$ edition), New Delhi, Prentice Hall, of India Private Ltd.

Garg, P. \& Rastogi, R. (2006). New model of job design: motivating employees performance, Journal of Management Development, Vol. 25, No. 6, pp 572-587. http://dx.doi.org/10.1108/02621710610670137 
Gerhart, B. \& Milkovich, G. T. (1992). Employee Compensation: Researc h and practice. In M. D. Dunnette \& L. M. Hough (Eds), Handbook of Industrial and organizational psychology, Vol. 3, $2^{\text {nd }}$ ed., pp 481-570, Palo Alto, CA: Consulting Psychologists Press.

Greasley, K., Bryman, A., Dainty, A., Price, A., Soetanto, R., \& King, N., (2005). Employee perceptions of empowerment, Employee Relations Journal, Vol 27, No. 4, pp 354-368. http://dx.doi.org/10.1108/01425450510605697

Hackman, J.R., \& Oldham, R.G. (1976). Motivation through the design of work: test of a theory, Organizational Behavior and Human Performance, Vol. 16 pp.250-79. http://dx.doi.org/10.1016/0030-5073(76)90016-7

Jackson, S. E. \& Schuler, R. S. (2000). Managing Human Resources: A Partnership Perspective. Ohio, South-Western College Publishing.

Johnson, P.R. (1994). Brains, heart and courage: keys to empowerment and self-directed leadership, Journal of Managerial Psychology, Vol. 9 No.2, pp.17-21. http://dx.doi.org/10.1108/02683949410059262

Knoke, D. \& Kalleberg, A. L. (1994). Job Training in U. S. Organizations, American Sociological Review, 59: 537-546. http://dx.doi.org/10.2307/2095930

Lawler, E.E., Mohram, S.A., \& Ledford, G.E. (1992). Employee Involvement and Total Quality Management: Practices and Results in Fortune 1000 Companies., Jossey-Bass, San Francisco, CA, .

Miller, K. \& Monge, P. (1986). Participation, Satisfaction and Productivity: A Meta-analytic Review, Academy of Management Journal, Vol 29, pp 727-753. http://dx.doi.org/10.2307/255942

Mullins, L.J., \& Peacock, A. (1991). Managing through people: regulating the employment relationship, Administrator, December, pp.45-55.

Noe, R. A., Hollenbeck, J. R., Gerhart, B., \& Wright, P. M. (2007). Human Resource Management: Gaining a competitive advantage ( $5^{\text {th }}$ edition) New Delhi, Tata McGraw-Hill Publishing Company Ltd.

Nykodym, N., Simonett, J. L. \& Welling, B. (1994). Employee Empowerment, Empowerment in Organizations Journal, Vol. 2 No. 3, pp. 45-55. http://dx.doi.org/10.1108/09684899410071699

Pastor, J. (1996). Empowerment: What it is and what it is not, Empowerment in Organizations Journal, Vol. 4, No. 2, pp. 5-7. http://dx.doi.org/10.1108/09684899610118028

Pfeffer, J. (1994). Competitive advantage through people: Unleashing the power of the work force, Boston, Harvard Business School Press

Psoinos, A. \& Smithson, S. (2002). Employee empowerment in manufacturing: a study of organisations in the UK, New Technology, Work and Employment, Vol. 17 No.2, pp.132-48. http://dx.doi.org/10.1111/1468-005X.00099

Smith, B. (1997). Empowerment the challenge is now, Empowerment in Organizations Journal, Vol. 5, No. 3, pp 120-122. http://dx.doi.org/10.1108/14634449710180008

Smith, C. S. \& Brannick, M. T. (1990). A role and expectancy model of participative decision-making. A replication and theoretical extension, Journal of Organizational Behaviour, Vol. 11, pp. 91-104. http://dx.doi.org/10.1002/job.4030110202

Wagner, J. A. \& Gooding, R. Z. (1987). Shared influence and organizational behaviour: A meta-analysis of situational variables expected to moderate participation-outcome relationships, Academy of Management Journal, Vol. 30, No. 3, pp 524-541. http://dx.doi.org/10.2307/256012

Table 1. Gender

\begin{tabular}{|c|c|c|c|}
\hline \multicolumn{2}{|c|}{} & Frequency & Percent \\
\hline \multirow{3}{*}{} & male & 19 & 57.6 \\
\cline { 2 - 4 } & female & 14 & 42.4 \\
\cline { 2 - 4 } & Total & 33 & 100.0 \\
\hline
\end{tabular}


Table 2. Highest level of education

\begin{tabular}{|c|c|c|c|}
\hline \multicolumn{2}{|c|}{} & Frequency & Percent \\
\hline O-Level & 3 & 9.1 \\
\cline { 2 - 4 } & diploma/certificate & 11 & 33.3 \\
\hline bachelors & 16 & 48.5 \\
\hline masters & 3 & 9.1 \\
\hline Total & 33 & 100.0 \\
\hline
\end{tabular}

Table 3. Job grade

\begin{tabular}{|c|c|c|c|}
\hline \multicolumn{2}{|c|}{} & Frequency & Percent \\
\hline \multirow{4}{*}{$\mathrm{m} 2$} & 2 & 6.1 \\
\cline { 2 - 3 } $\mathrm{m} 5$ & 4 & 12.1 \\
\hline $\mathrm{m} 6$ & 1 & 3.0 \\
\hline $\mathrm{m} 7$ & 5 & 15.2 \\
\hline $\mathrm{m} 8$ & 2 & 6.1 \\
\hline $\mathrm{m} 9$ & 2 & 6.1 \\
\hline $\mathrm{m} 10$ & 3 & 9.1 \\
\hline other & 14 & 42.4 \\
\cline { 2 - 4 } Total & 33 & 100.0 \\
\hline
\end{tabular}

Table 4. Attendance of training

\begin{tabular}{|c|c|c|c|}
\hline \multicolumn{2}{|c|}{} & Frequency & Percent \\
\hline \multirow{7}{*}{} & yes & 22 & 68.8 \\
\cline { 2 - 4 } & no & 9 & 28.1 \\
\cline { 2 - 4 } & 3 & 1 & 3.1 \\
\cline { 2 - 4 } & Total & 32 & 100.0 \\
\hline Missing & System & 1 & \\
\hline \multicolumn{2}{|c|}{ Total } & 33 & \\
\hline
\end{tabular}

Table 5. Type of training

\begin{tabular}{|c|c|c|c|}
\hline \multicolumn{2}{|c|}{} & Frequency & Percent \\
\hline \multirow{4}{*}{} & job related & 13 & 40.6 \\
\cline { 2 - 4 } & performance related & 1 & 3.1 \\
\cline { 2 - 4 } & continuous dev & 18 & 56.3 \\
\cline { 2 - 4 } & Total & 32 & 100.0 \\
\hline Missing & System & 1 & \\
\hline \multicolumn{2}{|c|}{ Total } & 33 & \\
\hline
\end{tabular}

Table 6. Who paid for the course?

\begin{tabular}{|c|c|c|}
\hline & Frequency & Percent \\
\hline employer & 15 & 45.5 \\
\hline self & 5 & 15.2 \\
\hline Other & 13 & 39.4 \\
\hline Total & 33 & 100.0 \\
\hline
\end{tabular}


Table 7. Duration of the course

\begin{tabular}{|c|c|c|c|}
\hline \multicolumn{2}{|c|}{} & Frequency & Percent \\
\hline \multirow{7}{*}{} & $0-4$ wks & 9 & 28.1 \\
\cline { 2 - 4 } & 4-8wks & 5 & 15.6 \\
\cline { 2 - 4 } & over 2months & 17 & 53.1 \\
\cline { 2 - 4 } & other & 1 & 3.1 \\
\cline { 2 - 4 } & Total & 32 & 100.0 \\
\hline Missing & System & 1 & \\
\hline \multicolumn{2}{|c|}{ Total } & 33 & \\
\hline
\end{tabular}

Table 8. Was the training related to the work you are doing

\begin{tabular}{|c|c|c|}
\hline & Frequency & Percent \\
\hline yes & 15 & 45.5 \\
\hline no & 5 & 15.2 \\
\hline N/A & 13 & 39.4 \\
\hline Total & 33 & 100.0 \\
\hline
\end{tabular}

Table 9. Consulted or interviewed before the training

\begin{tabular}{|c|c|c|}
\hline & Frequency & Percent \\
\hline yes & 5 & 15.2 \\
\hline no & 15 & 45.5 \\
\hline 3 & 13 & 39.4 \\
\hline Total & 33 & 100.0 \\
\hline
\end{tabular}

Table 10. Training useful in helping you perform your tasks better

\begin{tabular}{|c|c|c|c|}
\hline \multicolumn{2}{|c|}{} & Frequency & Percent \\
\hline & yes & 16 & 48.5 \\
\hline no & 4 & 12.1 \\
\hline 3 & 13 & 39.4 \\
\hline Total & 33 & 100.0 \\
\hline
\end{tabular}

Table 11. Was there a difference in feedback given to you by supervisor?

\begin{tabular}{|c|c|c|}
\hline & Frequency & Percent \\
\hline yes & 12 & 36.4 \\
\hline no & 7 & 21.2 \\
\hline 3 & 14 & 42.4 \\
\hline Total & 33 & 100.0 \\
\hline
\end{tabular}


Table 12. Did the feedback indicate an improvement in performance?

\begin{tabular}{|c|c|c|c|}
\hline \multicolumn{2}{|c|}{} & Frequency & Percent \\
\hline \multirow{4}{*}{ yes } & 12 & 36.4 \\
\cline { 2 - 4 } & no & 7 & 21.2 \\
\hline 3 & 14 & 42.4 \\
\cline { 2 - 4 } & Total & 33 & 100.0 \\
\hline
\end{tabular}

Table 13. Basis of rewards in your organization

\begin{tabular}{|c|c|c|c|}
\hline & Frequency & Percent \\
\hline & performance & 7 & 23.3 \\
\hline & skills & 5 & 16.7 \\
\hline & competence & 5 & 16.7 \\
\hline & length of service & 9 & 30.0 \\
\hline & other & 4 & 13.3 \\
\hline & Total & 30 & 100.0 \\
\hline Missing & System & 3 & \\
\hline & Total & 33 & \\
\hline
\end{tabular}

Table 14. What basis is salary increments effected?

\begin{tabular}{|c|c|c|}
\hline & Frequency & Percent \\
\hline annual increments & 25 & 75.8 \\
\hline performance & 1 & 3.0 \\
\hline additional skills & 7 & 21.2 \\
\hline Total & 33 & 100.0 \\
\hline
\end{tabular}

Table 15. Perceive fairness in the way salary increments are affected

\begin{tabular}{|c|c|c|c|}
\hline \multicolumn{2}{|c|}{} & Frequency & Percent \\
\hline \multirow{4}{*}{ yes } & 11 & 33.3 \\
\cline { 2 - 4 } & no & 22 & 66.7 \\
\cline { 2 - 4 } & Total & 33 & 100.0 \\
\hline
\end{tabular}

Table 16. Supervisor clearly define the performance targets that you are expected

\begin{tabular}{|c|c|c|c|}
\hline \multicolumn{2}{|c|}{} & Frequency & Percent \\
\hline yes & 19 & 57.6 \\
\cline { 2 - 4 } & no & 13 & 39.4 \\
\hline 3 & 1 & 3.0 \\
\cline { 2 - 4 } & Total & 33 & 100.0 \\
\hline
\end{tabular}

Table 17. In your opinion are the performance targets achievable

\begin{tabular}{|c|c|c|c|}
\hline \multicolumn{2}{|c|}{} & Frequency & Percent \\
\hline \multirow{4}{*}{} & yes & 21 & 65.6 \\
\cline { 2 - 4 } & no & 11 & 34.4 \\
\cline { 2 - 4 } & Total & 32 & 100.0 \\
\hline Missing & System & 1 & \\
\hline \multicolumn{2}{|c|}{ Total } & 33 & \\
\hline
\end{tabular}


Table 18. You receive feedback from your supervisor on how well or poorly you have

\begin{tabular}{|c|c|c|c|}
\hline \multicolumn{2}{|c|}{} & Frequency & Percent \\
\hline \multirow{4}{*}{} & yes & 18 & 56.3 \\
\cline { 2 - 4 } & no & 11 & 34.4 \\
\cline { 2 - 4 } & 3 & 2 & 6.3 \\
\cline { 2 - 4 } & 4 & 1 & 3.1 \\
\cline { 2 - 4 } & Total & 32 & 100.0 \\
\hline Missing & System & 1 & \\
\hline \multicolumn{2}{|c|}{ Total } & 33 & \\
\hline
\end{tabular}

Table 19. How often is the feedback given?

\begin{tabular}{|c|c|c|c|}
\hline \multicolumn{2}{|c|}{} & Frequency & Percent \\
\hline \multirow{4}{*}{} & every 1 month & 7 & 26.9 \\
\cline { 2 - 4 } & every 3months & 8 & 30.8 \\
\cline { 2 - 4 } & every 6 months & 1 & 3.8 \\
\cline { 2 - 4 } & annually & 10 & 38.5 \\
\cline { 2 - 4 } & Total & 26 & 100.0 \\
\hline Missing & System & 7 & \\
\hline \multicolumn{2}{|c|}{ Total } & 33 & \\
\hline \multicolumn{2}{|c|}{} &
\end{tabular}

Table 20. You receive any financial rewards or salary increase

\begin{tabular}{|c|c|c|c|}
\hline \multicolumn{2}{|c|}{} & Frequency & Percent \\
\hline \multirow{4}{*}{} & yes & 8 & 25.0 \\
\cline { 2 - 4 } & no & 23 & 71.9 \\
\cline { 2 - 4 } & 3 & 1 & 3.1 \\
\cline { 2 - 4 } & Total & 32 & 100.0 \\
\hline Missing & System & 1 & \\
\hline \multicolumn{2}{|c|}{ Total } & 33 & \\
\hline
\end{tabular}

Table 21. You value the financial rewards or salary increase

\begin{tabular}{|c|c|c|c|}
\hline \multicolumn{2}{|c|}{} & Frequency & Percent \\
\hline \multirow{4}{*}{} & yes & 10 & 33.3 \\
\cline { 2 - 4 } & no & 19 & 63.3 \\
\cline { 2 - 4 } & 3 & 1 & 3.3 \\
\cline { 2 - 4 } & Total & 30 & 100.0 \\
\hline Missing & System & 3 & \\
\hline \multicolumn{2}{|c|}{ Total } & 33 & \\
\hline
\end{tabular}

Table 22. The rewards motivate you to improve performance

\begin{tabular}{|c|c|c|c|}
\hline \multicolumn{2}{|c|}{} & Frequency & Percent \\
\hline \multirow{4}{*}{} & yes & 14 & 50.0 \\
\cline { 2 - 4 } & no & 12 & 42.9 \\
\cline { 2 - 4 } & 3 & 2 & 7.1 \\
\cline { 2 - 4 } & Total & 28 & 100.0 \\
\hline Missing & System & 5 & \\
\hline \multicolumn{2}{|c|}{ Total } & 33 & \\
\hline
\end{tabular}


Table 23. You think your performance affects the performance

\begin{tabular}{|c|c|c|c|}
\hline \multicolumn{2}{|c|}{} & Frequency & Percent \\
\hline \multirow{4}{*}{} & yes & 30 & 90.9 \\
\cline { 2 - 4 } & no & 3 & 9.1 \\
\cline { 2 - 4 } & Total & 33 & 100.0 \\
\hline
\end{tabular}

Table 24. Nature of the effect

\begin{tabular}{|c|c|c|c|}
\hline \multicolumn{2}{|c|}{} & Frequency & Percent \\
\hline \multirow{4}{*}{ positively } & 27 & 81.8 \\
\cline { 2 - 4 } negatively & 2 & 6.1 \\
\hline 4 & 3 & 9.1 \\
\hline 5 & 1 & 3.0 \\
\hline Total & 33 & 100.0 \\
\cline { 2 - 4 }
\end{tabular}

Table 25. Being allowed to exercise control over my work

\begin{tabular}{|c|c|c|}
\hline & Frequency & Percent \\
\hline not at all & 1 & 3.0 \\
\hline to a moderate extent & 1 & 3.0 \\
\hline to a large extent & 30 & 90.9 \\
\hline to a very large extent & 1 & 3.0 \\
\hline Total & 33 & 100.0 \\
\hline
\end{tabular}

Table 26. Exercising initiative and creativity in my work

\begin{tabular}{|c|c|c|}
\hline & Frequency & Percent \\
\hline to a moderate extent & 3 & 9.1 \\
\hline to a large extent & 29 & 87.9 \\
\hline to a very large extent & 1 & 3.0 \\
\hline Total & 33 & 100.0 \\
\hline
\end{tabular}

Table 27. Challenging tasks

\begin{tabular}{|c|c|c|}
\hline & Frequency & Percent \\
\hline to a less extent & 1 & 3.0 \\
\hline to a moderate extent & 11 & 33.3 \\
\hline to a large extent & 21 & 63.6 \\
\hline Total & 33 & 100.0 \\
\hline
\end{tabular}

Table 28. Deciding how to go about my tasks

\begin{tabular}{|c|c|c|}
\hline & Frequency & Percent \\
\hline to a moderate extent & 6 & 18.2 \\
\hline to a large extent & 21 & 63.6 \\
\hline to a very large extent & 6 & 18.2 \\
\hline Total & 33 & 100.0 \\
\hline
\end{tabular}


Table 29. Opportunity to make decisions that I can handle

\begin{tabular}{|c|c|c|c|}
\hline \multicolumn{2}{|c|}{} & Frequency & Percent \\
\hline & to a moderate extent & 2 & 6.1 \\
\cline { 2 - 4 } & to a large extent & 12 & 36.4 \\
\cline { 2 - 4 } & to a very large extent & 19 & 57.6 \\
\cline { 2 - 4 } & Total & 33 & 100.0 \\
\hline
\end{tabular}

Table 30. My input being sought in managerial decisions

\begin{tabular}{|c|c|c|c|}
\hline \multicolumn{2}{|c|}{} & Frequency & Percent \\
\hline & to a moderate extent & 1 & 3.0 \\
\hline & to a large extent & 5 & 15.2 \\
\cline { 2 - 4 } & to a very large extent & 27 & 81.8 \\
\cline { 2 - 4 } & Total & 33 & 100.0 \\
\hline
\end{tabular}

Table 31. Being delegated to tasks that I can handle

\begin{tabular}{|c|c|c|c|}
\hline \multicolumn{2}{|c|}{} & Frequency & Percent \\
\hline \multirow{2}{*}{ to a moderate extent } & 9 & 27.3 \\
\cline { 2 - 4 } & to a large extent & 14 & 42.4 \\
\cline { 2 - 4 } & to a very large extent & 10 & 30.3 \\
\cline { 2 - 4 } & Total & 33 & 100.0 \\
\hline
\end{tabular}

Table 32. Assurance of job security as long as I can perform

\begin{tabular}{|c|c|c|c|}
\hline \multicolumn{2}{|c|}{} & Frequency & Percent \\
\hline & to a moderate extent & 1 & 3.0 \\
\hline & to a large extent & 1 & 3.0 \\
\hline to a very large extent & 31 & 93.9 \\
\cline { 2 - 4 } & Total & 33 & 100.0 \\
\hline
\end{tabular}

Table 33. Being equipped with skills required by my job

\begin{tabular}{|l|l|c|c|}
\hline \multicolumn{2}{|l|}{} & Frequency & Percent \\
\hline & to a very large extent & 33 & 100.0 \\
\hline
\end{tabular}

Table 34. Setting of achievable targets

\begin{tabular}{|l|c|c|c|}
\hline \multicolumn{2}{|l|}{} & Frequency & Percent \\
\hline & to a very large extent & 33 & 100.0 \\
\hline
\end{tabular}

Table 35. My input in setting of targets

\begin{tabular}{|c|c|c|c|}
\hline \multicolumn{2}{|c|}{} & Frequency & Percent \\
\hline & to a very large extent & 32 & 100.0 \\
\hline Missing & System & 1 & \\
\hline \multicolumn{2}{|c|}{ Total } & 33 & \\
\hline
\end{tabular}

Table 36. Fair evaluation of performance

\begin{tabular}{|c|c|c|c|}
\hline \multicolumn{2}{|c|}{} & Frequency & Percent \\
\hline \multirow{4}{*}{ to a large extent } & 2 & 6.1 \\
\cline { 2 - 4 } to a very large extent & 31 & 93.9 \\
\cline { 2 - 4 } & Total & 33 & 100.0 \\
\hline
\end{tabular}


Table 37. Feedback on performance

\begin{tabular}{|c|c|c|}
\hline & Frequency & Percent \\
\hline to a large extent & 24 & 72.7 \\
\hline to a very large extent & 9 & 27.3 \\
\hline Total & 33 & 100.0 \\
\hline
\end{tabular}

Table 38. Salary increase on achievement of set targets

\begin{tabular}{|c|c|c|}
\hline & Frequency & Percent \\
\hline to a large extent & 1 & 3.0 \\
\hline to a very large extent & 32 & 97.0 \\
\hline Total & 33 & 100.0 \\
\hline
\end{tabular}

Table 39. Bonuses and incentives on achievement of targets

\begin{tabular}{|c|c|c|}
\hline & Frequency & Percent \\
\hline to a large extent & 1 & 3.0 \\
\hline to a very large extent & 32 & 97.0 \\
\hline Total & 33 & 100.0 \\
\hline
\end{tabular}

Table 40. Fair administration of rewards

\begin{tabular}{|c|c|c|}
\hline & Frequency & Percent \\
\hline to a large extent & 2 & 6.1 \\
\hline to a very large extent & 31 & 93.9 \\
\hline Total & 33 & 100.0 \\
\hline
\end{tabular}

Table 41. Descriptive statistics

\begin{tabular}{|c|c|c|c|c|c|}
\hline & $\mathrm{N}$ & Minimum & Maximum & Mean & Std. Deviation \\
\hline Gender & 33 & 1 & 2 & 1.42 & .502 \\
\hline Highest level of education & 33 & 2 & 5 & 3.58 & .792 \\
\hline length of service & 33 & 1 & 3 & 1.36 & .603 \\
\hline job grade & 33 & 1 & 8 & 5.70 & 2.506 \\
\hline Attendance of training & 32 & 1 & 3 & 1.34 & .545 \\
\hline type of training & 32 & 1 & 3 & 2.16 & .987 \\
\hline who paid for the course & 33 & 1 & 3 & 1.94 & .933 \\
\hline duration of the course & 32 & 1 & 4 & 2.31 & .931 \\
\hline $\begin{array}{c}\text { Was the training related to } \\
\text { the work you are doing }\end{array}$ & 33 & 1 & 3 & 1.94 & .933 \\
\hline $\begin{array}{c}\text { consulted or interviewed } \\
\text { before the training }\end{array}$ & 33 & 1 & 3 & 2.24 & .708 \\
\hline $\begin{array}{c}\text { training useful in helping } \\
\text { you perform your tasks } \\
\text { better }\end{array}$ & 33 & 1 & 3 & 1.91 & .947 \\
\hline $\begin{array}{c}\text { Was there a difference in } \\
\text { feedback given to you by } \\
\text { supervisor }\end{array}$ & 33 & 1 & 3 & 2.06 & .899 \\
\hline $\begin{array}{c}\text { did the feedback indicate } \\
\text { an improvement in } \\
\text { performance }\end{array}$ & 33 & 1 & 3 & 2.06 & .899 \\
\hline
\end{tabular}




\begin{tabular}{|c|c|c|c|c|c|}
\hline $\begin{array}{c}\text { basis of rewards in your } \\
\text { organization }\end{array}$ & 30 & 1 & 5 & 2.93 & 1.413 \\
\hline $\begin{array}{l}\text { what basis are salary } \\
\text { increments effected }\end{array}$ & 33 & 1 & 3 & 1.45 & .833 \\
\hline $\begin{array}{l}\text { perceive fairness in the way } \\
\text { salary increments are } \\
\text { effected }\end{array}$ & 33 & 1 & 2 & 1.67 & .479 \\
\hline $\begin{array}{l}\text { supervisor clearly define } \\
\text { the performance targets } \\
\text { that you are expected }\end{array}$ & 33 & 1 & 3 & 1.45 & .564 \\
\hline $\begin{array}{l}\text { in your opinion are the } \\
\text { performance targets } \\
\text { achievable }\end{array}$ & 32 & 1 & 2 & 1.34 & .483 \\
\hline $\begin{array}{l}\text { you receive feedback from } \\
\text { your supervisor on how } \\
\text { well or poorly you have }\end{array}$ & 32 & 1 & 4 & 1.56 & .759 \\
\hline $\begin{array}{l}\text { how often is the feedback } \\
\text { given }\end{array}$ & 26 & 1 & 4 & 2.54 & 1.272 \\
\hline $\begin{array}{l}\text { you receive any financial } \\
\text { rewards or salary increase }\end{array}$ & 32 & 1 & 3 & 1.78 & .491 \\
\hline $\begin{array}{l}\text { you value the financial } \\
\text { rewards or salary increase }\end{array}$ & 30 & 1 & 3 & 1.70 & .535 \\
\hline $\begin{array}{l}\text { the rewards motivate you to } \\
\text { improve performance }\end{array}$ & 28 & 1 & 3 & 1.57 & .634 \\
\hline $\begin{array}{c}\text { you think your } \\
\text { performance affects the } \\
\text { performance }\end{array}$ & 33 & 1 & 2 & 1.09 & .292 \\
\hline nature of the effect & 33 & 1 & 5 & 1.45 & 1.092 \\
\hline $\begin{array}{l}\text { Being allowed to exercise } \\
\text { control over my work }\end{array}$ & 33 & 1 & 5 & 3.91 & .579 \\
\hline $\begin{array}{l}\text { Exercising initiative and } \\
\text { creativity in my work }\end{array}$ & 33 & 3 & 5 & 3.94 & .348 \\
\hline Challenging tasks & 33 & 2 & 4 & 3.61 & .556 \\
\hline $\begin{array}{l}\text { Deciding how to go about } \\
\text { my tasks }\end{array}$ & 33 & 3 & 5 & 4.00 & .612 \\
\hline $\begin{array}{c}\text { Opportunity to make } \\
\text { decisions that I can handle }\end{array}$ & 33 & 3 & 5 & 4.52 & .619 \\
\hline $\begin{array}{l}\text { My input being sought in } \\
\text { managerial decisions }\end{array}$ & 33 & 3 & 5 & 4.79 & .485 \\
\hline $\begin{array}{l}\text { Being delegated to tasks } \\
\text { that I can handle }\end{array}$ & 33 & 3 & 5 & 4.03 & .770 \\
\hline $\begin{array}{l}\text { Assurance of job security } \\
\text { as long as I can perform }\end{array}$ & 33 & 3 & 5 & 4.91 & .384 \\
\hline $\begin{array}{l}\text { Being equipped with skills } \\
\text { required by my job }\end{array}$ & 33 & 5 & 5 & 5.00 & .000 \\
\hline $\begin{array}{l}\text { Opportunity to acquire } \\
\text { additional skills }\end{array}$ & 33 & 5 & 5 & 5.00 & .000 \\
\hline $\begin{array}{c}\text { Refresher courses that are } \\
\text { job-related }\end{array}$ & 33 & 5 & 5 & 5.00 & .000 \\
\hline
\end{tabular}




\begin{tabular}{|c|c|c|c|c|c|}
\hline $\begin{array}{c}\text { Setting of achievable } \\
\text { targets }\end{array}$ & 33 & 5 & 5 & 5.00 & .000 \\
\hline $\begin{array}{c}\text { My input in setting of } \\
\text { targets }\end{array}$ & 32 & 5 & 5 & 5.00 & .000 \\
\hline $\begin{array}{c}\text { Fair evaluation of } \\
\text { performance }\end{array}$ & 33 & 4 & 5 & 4.94 & .242 \\
\hline Feedback on performance & 33 & 4 & 5 & 4.27 & .452 \\
\hline $\begin{array}{c}\text { Salary increase on } \\
\text { achievement of set targets }\end{array}$ & 33 & 4 & 5 & 4.97 & .174 \\
\hline $\begin{array}{c}\text { Bonuses and incentives on } \\
\text { achievement of targets }\end{array}$ & 33 & 4 & 5 & 4.97 & .174 \\
\hline $\begin{array}{c}\text { Fair administration of } \\
\text { rewards }\end{array}$ & 33 & 4 & 5 & 4.94 & .242 \\
\hline Valid N (listwise) & 21 & & & & \\
\hline
\end{tabular}

Table 42. Correlation analysis

\begin{tabular}{|c|c|c|c|c|c|c|c|c|c|c|c|c|c|c|c|c|c|c|c|}
\hline & & 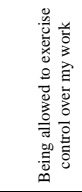 & 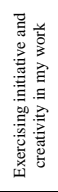 & 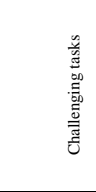 & 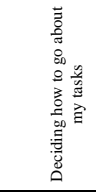 & 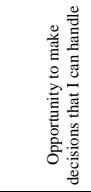 & 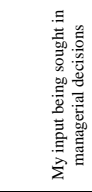 & 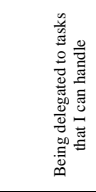 & 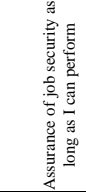 & 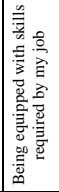 & 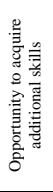 & 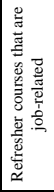 & 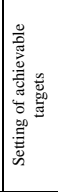 & 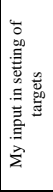 & 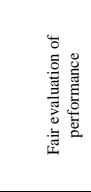 & 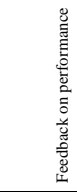 & 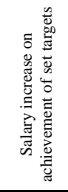 & 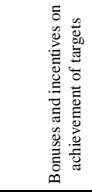 & 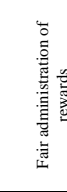 \\
\hline 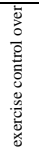 & 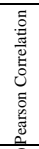 & 1 & .127 & -.018 & .176 & $.484(* *)$ & -.182 & -.064 & $.383(*)$ & (a) & .(a) & (a) & (a) & .(a) & -.040 & .098 & -.028 & -.028 & -.040 \\
\hline 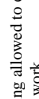 & 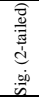 & . & .482 & .922 & .326 & .004 & .310 & .725 & .028 & . & . & . & & . & .823 & .589 & .876 & .876 & .823 \\
\hline 政 & $z$ & 33 & 33 & 33 & 33 & 33 & 33 & 33 & 33 & 33 & 33 & 33 & 33 & 32 & 33 & 33 & 33 & 33 & 33 \\
\hline 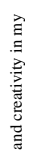 & 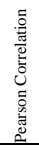 & .127 & 1 & .196 & .293 & .004 & -.264 & .240 & -.042 & (a) & .(a) & .(a) & (a) & (a) & -.045 & -.090 & -.031 & -.031 & .326 \\
\hline 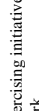 & 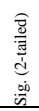 & .482 & . & .275 & .098 & .981 & .138 & .178 & .815 & . & . & . & . & . & .804 & .618 & .863 & .863 & .065 \\
\hline 畜 & $z$ & 33 & 33 & 33 & 33 & 33 & 33 & 33 & 33 & 33 & 33 & 33 & 33 & 32 & 33 & 33 & 33 & 33 & 33 \\
\hline \multirow{3}{*}{ 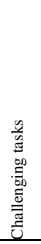 } & 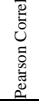 & -.018 & .196 & 1 & $.551(* *)$ & $.518(* *)$ & -.088 & .102 & $.412(*)$ & (a) & (a) & (a) & .(a) & (a) & $.513(* *)$ & .068 & -.127 & $.519(* *)$ & .281 \\
\hline & 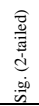 & .922 & .275 & . & .001 & .002 & .627 & .573 & .017 & . & . & . & . & . & .002 & .708 & .480 & .002 & .113 \\
\hline & $z$ & 33 & 33 & 33 & 33 & 33 & 33 & 33 & 33 & 33 & 33 & 33 & 33 & 32 & 33 & 33 & 33 & 33 & 33 \\
\hline \multirow{2}{*}{ 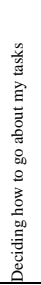 } & 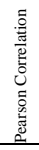 & .176 & .293 & $.551(* *)$ & 1 & $.413(*)$ & $-.421(*)$ & $.464(* *)$ & .266 & (a) & (a) & .(a) & (a) & (a) & .211 & .113 & -.293 & .293 & .000 \\
\hline & $z$ & 33 & 33 & 33 & 33 & 33 & 33 & 33 & 33 & 33 & 33 & 33 & 33 & 32 & 33 & 33 & 33 & 33 & 33 \\
\hline
\end{tabular}




\begin{tabular}{|c|c|c|c|c|c|c|c|c|c|c|c|c|c|c|c|c|c|c|c|}
\hline 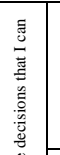 & 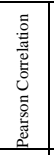 & $.484(* *)$ & . 004 & $.518(* *)$ & $.413(*)$ & 1 & -.145 & -.034 & $.598\left({ }^{(* *}\right)$ & .(a) & .(a) & .(a) & .(a) & .(a) & $.423\left(^{*}\right)$ & .152 & . 150 & $.440(*)$ & . 006 \\
\hline 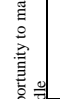 & 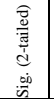 & .004 & . 981 & .002 & .017 & . & .420 & .852 & .000 & . & . & . & . & . & .014 & .397 & .406 & .010 & .972 \\
\hline 言謷 & $z$ & 33 & 33 & 33 & 33 & 33 & 33 & 33 & 33 & 33 & 33 & 33 & 33 & 32 & 33 & 33 & 33 & 33 & 33 \\
\hline 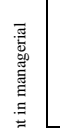 & 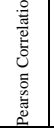 & -182 & -.264 & -.088 & $-.421(*)$ & -.145 & 1 & $-.569(* *)$ & .229 & .(a) & .(a) & .(a) & .(a) & .(a) & .153 & .130 & -.079 & .292 & -.113 \\
\hline 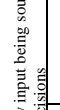 & 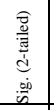 & .310 & . 138 & .627 & .015 & . 420 & . & .001 & .200 & . & . & . & . & . & .395 & .472 & . 664 & .099 & .532 \\
\hline$\sum$ & $z$ & 33 & 33 & 33 & 33 & 33 & 33 & 33 & 33 & 33 & 33 & 33 & 33 & 32 & 33 & 33 & 33 & 33 & 33 \\
\hline 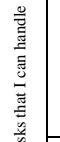 & 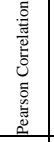 & -.064 & . 240 & . 102 & $.464(* *)$ & -.034 & $-.569(* *)$ & 1 & -.307 & .(a) & .(a) & .(a) & .(a) & .(a) & -.325 & -.024 & . 007 & -.226 & . 178 \\
\hline 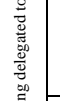 & 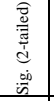 & .725 & . 178 & .573 & . 007 & .852 & .001 & . & .082 & . & & & . & . & . 065 & .892 & .969 & .206 & .323 \\
\hline 卷 & $z$ & 33 & 33 & 33 & 33 & 33 & 33 & 33 & 33 & 33 & 33 & 33 & 33 & 32 & 33 & 33 & 33 & 33 & 33 \\
\hline 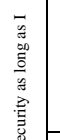 & 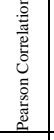 & $.383(*)$ & -.042 & $.412(*)$ & .266 & $.598\left({ }^{* *}\right)$ & .229 & -.307 & 1 & .(a) & .(a) & .(a) & .(a) & .(a) & $.610(* *)$ & .147 & -.042 & $.892(* *)$ & -.061 \\
\hline 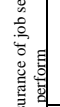 & 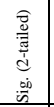 & .028 & .815 & .017 & .135 & .000 & .200 & .082 & . & . & . & . & . & . & .000 & .414 & .815 & .000 & .736 \\
\hline 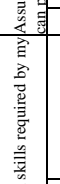 & 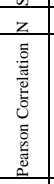 & .(a) & .(a) & .(a) & .(a) & .(a) & .(a) & .(a) & .(a) & .(a) & .(a) & .(a) & .(a) & .(a) & .(a) & .(a) & .(a) & 33 & .(a) \\
\hline 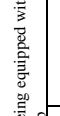 & 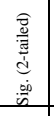 & . & . & . & . & & r & . & & . & & & . & . & . & . & 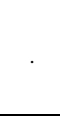 & . & \\
\hline 물. & $z$ & 33 & 33 & 33 & 33 & 33 & 33 & 33 & 33 & 33 & 33 & 33 & 33 & 32 & 33 & 33 & 33 & 33 & 33 \\
\hline 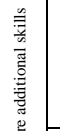 & 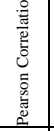 & .(a) & .(a) & .(a) & .(a) & .(a) & .(a) & .(a) & .(a) & .(a) & .(a) & .(a) & .(a) & .(a) & .(a) & .(a) & .(a) & .(a) & .(a) \\
\hline 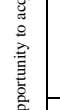 & 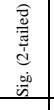 & . & . & . & . & & . & . & & . & 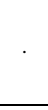 & & . & . & . & . & . & . & \\
\hline 亏ેे & z & 33 & 33 & 33 & 33 & 33 & 33 & 33 & 33 & 33 & 33 & 33 & 33 & 32 & 33 & 33 & 33 & 33 & 33 \\
\hline 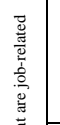 & 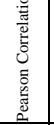 & .(a) & .(a) & .(a) & .(a) & .(a) & .(a) & .(a) & .(a) & .(a) & .(a) & .(a) & .(a) & .(a) & .(a) & .(a) & .(a) & .(a) & .(a) \\
\hline 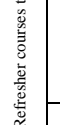 & 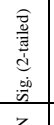 & 33 & 33 & 33 & 33 & 33 & . & . & . & . & 32 & . & . & . & . & . & . & . & . \\
\hline 苋 & $z$ & 33 & 33 & 33 & 33 & 33 & 33 & 33 & 33 & 33 & 33 & 33 & 33 & 32 & 33 & 33 & 33 & 33 & 33 \\
\hline & 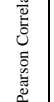 & .(a) & .(a) & .(a) & .(a) & .(a) & .(a) & .(a) & .(a) & .(a) & .(a) & .(a) & .(a) & .(a) & .(a) & .(a) & .(a) & .(a) & .(a) \\
\hline
\end{tabular}




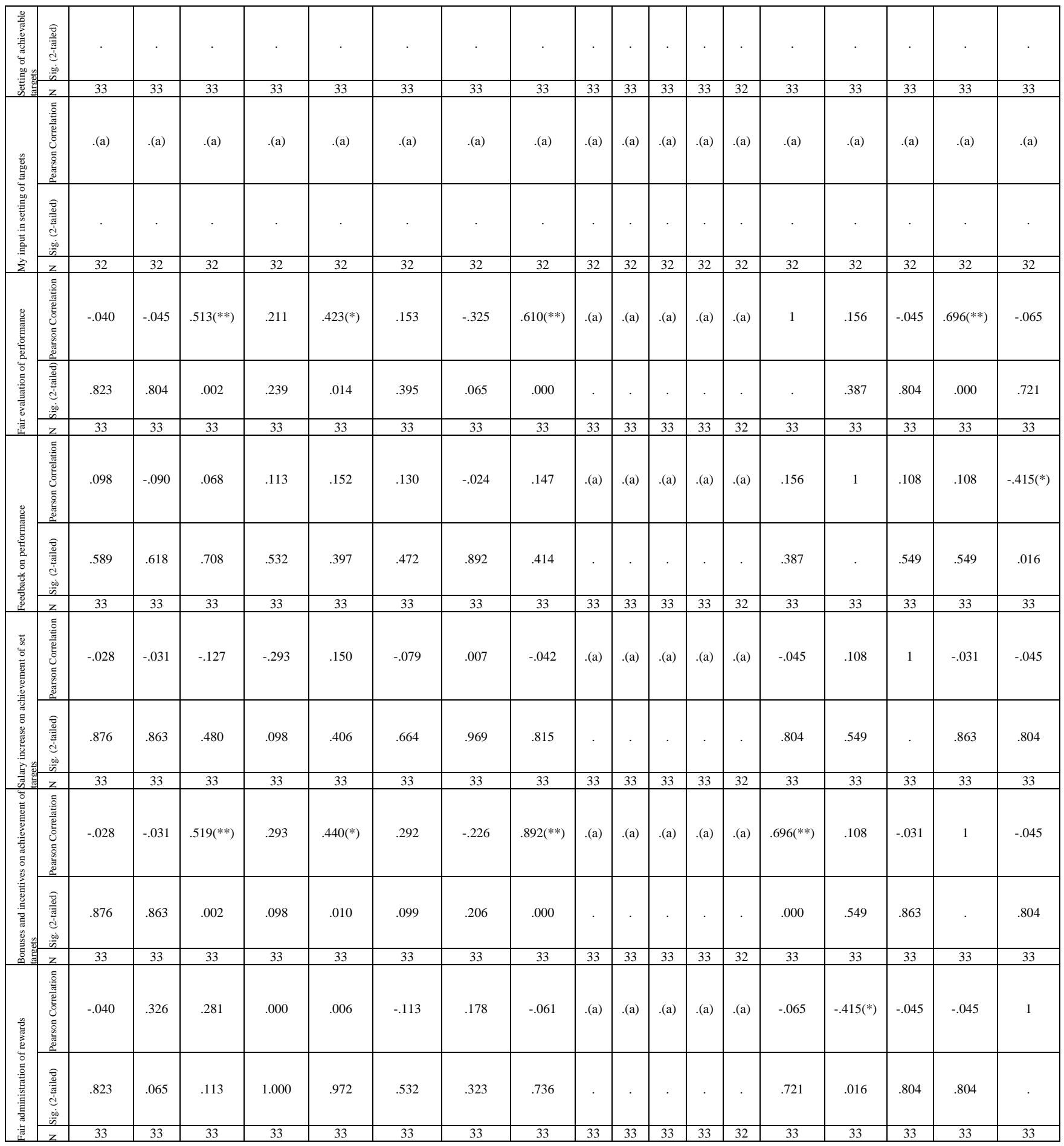

** Correlation is significant at the 0.01 level (2-tailed).

* Correlation is significant at the 0.05 level (2-tailed).

a Cannot be computed because at least one of the variables is constant. 
Table 43. Regression model

\begin{tabular}{|c|c|c|c|}
\hline Model & Variables Entered & $\begin{array}{c}\text { Variables } \\
\text { Removed }\end{array}$ & Method \\
\hline 1 & $\begin{array}{c}\text { performance-related pay , empowerment , job } \\
\text { design, job security, training(a) }\end{array}$ & $\cdot$ & Enter \\
\hline
\end{tabular}

Variables Entered/Removed (b)

a All requested variables entered.

b Dependent Variable: Performance

Table 44. Model summary

\begin{tabular}{|c|c|c|c|c|}
\hline Model & $\mathrm{R}$ & R Square & Adjusted R Square & Std. Error of the Estimate \\
\hline 1 & $.850(\mathrm{a})$ & .723 & .670 & .681 \\
\hline
\end{tabular}

a Predictors: (Constant), Performance-related pay, Empowerment , Job design, Job Security , Training

Table 45. ANOVA (b)

\begin{tabular}{|c|c|c|c|c|c|c|}
\hline Model & & Sum of Squares & df & Mean Square & $F$ & Sig. \\
\hline 1 & Regression & 31.423 & 5 & 6.285 & 13.565 & $.000(\mathrm{a})$ \\
\hline & Residual & 12.046 & 26 & .463 & & \\
\hline & Total & 43.469 & 31 & & & \\
\hline
\end{tabular}

a Predictors: (Constant), Performance-related pay , Empowerment , Job design, Job Security , Training

b Dependent Variable: Performance

Total variation $=$ total $=\sum(y-\bar{y})^{2}=43.469$

Error of variation $=$ residual $=\operatorname{SSE}=\sum(y-y 1)^{2}=12.046$

Regression variation $=\mathrm{SSR}=\mathrm{SS}$ total $-\mathrm{SSE}=43.469-12.046=31.423$

Table 46. Coefficients (a)

\begin{tabular}{|c|c|c|c|c|c|c|}
\hline Model & & \multicolumn{2}{|c|}{ Unstandardized Coefficients } & Standardized Coefficients & $\mathrm{t}$ & Sig. \\
\hline & & $\mathrm{B}$ & Std. Error & Beta & & \\
\hline 1 & (Constant) & .530 & .797 & & .664 & .512 \\
\hline & Job design & -.126 & .104 & -.130 & -1.206 & .239 \\
\hline & Empowerment & .060 & .132 & .051 & .455 & .653 \\
\hline & Job Security & -.058 & .087 & -.077 & -.669 & .509 \\
\hline & Training & .290 & .114 & .293 & 2.550 & .017 \\
\hline & Performance-related pay & .611 & .106 & .687 & 5.765 & .000 \\
\hline
\end{tabular}

a Dependent Variable: Performance 

Independent Variables
Dependent Variable

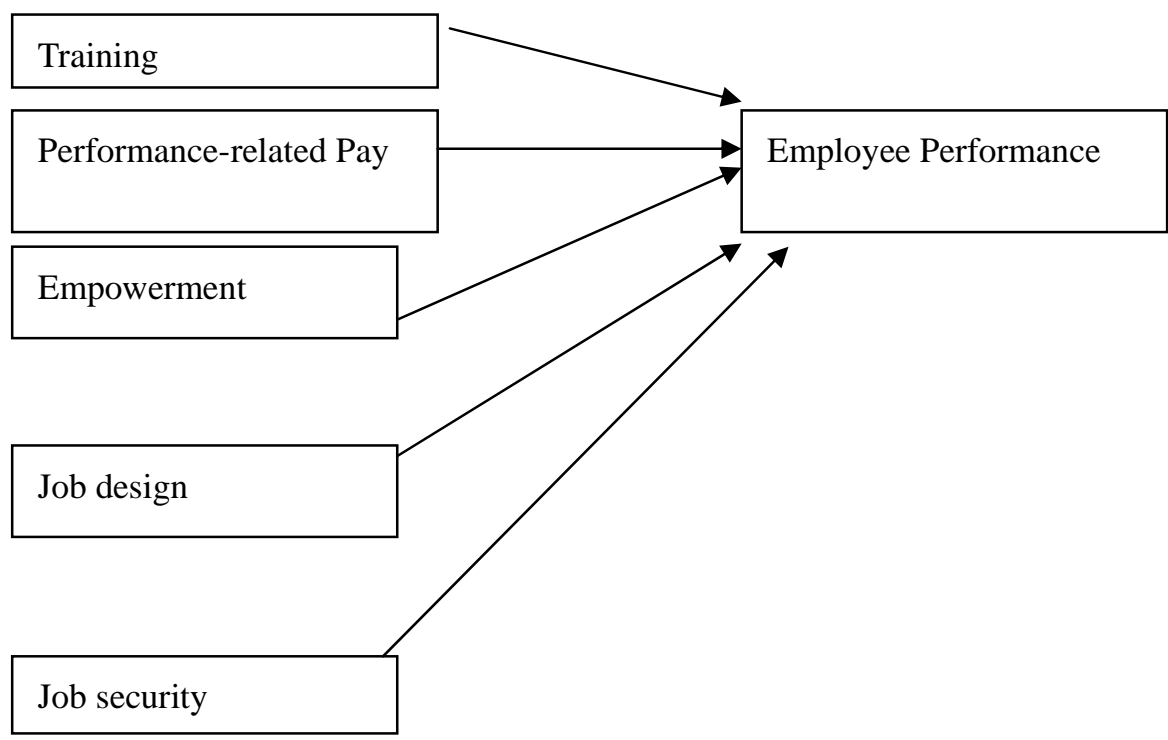

Figure 1. Source: Author (2011)

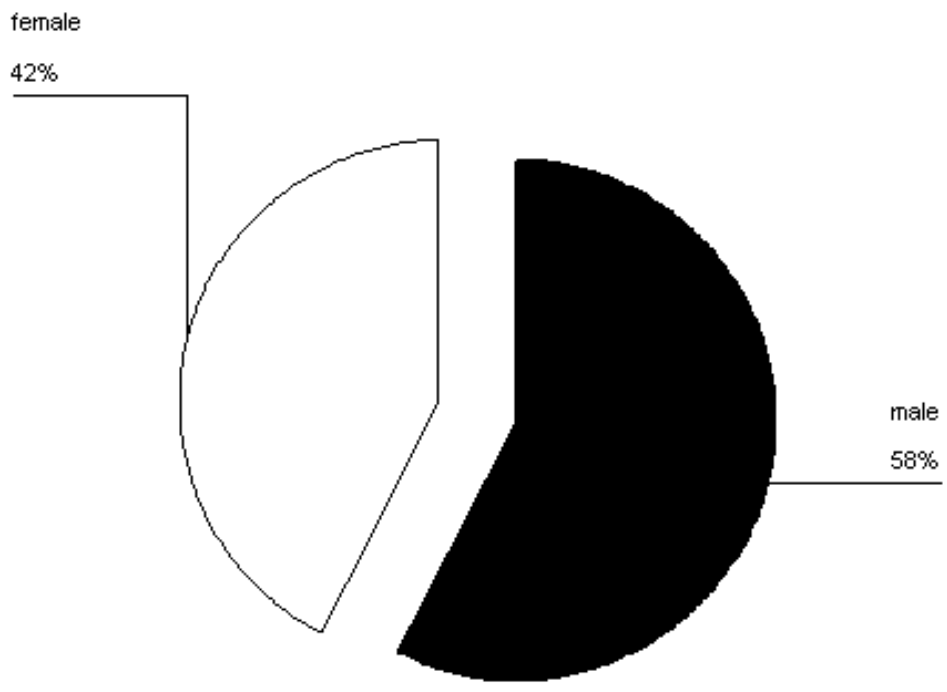

Figure 2. Gender 


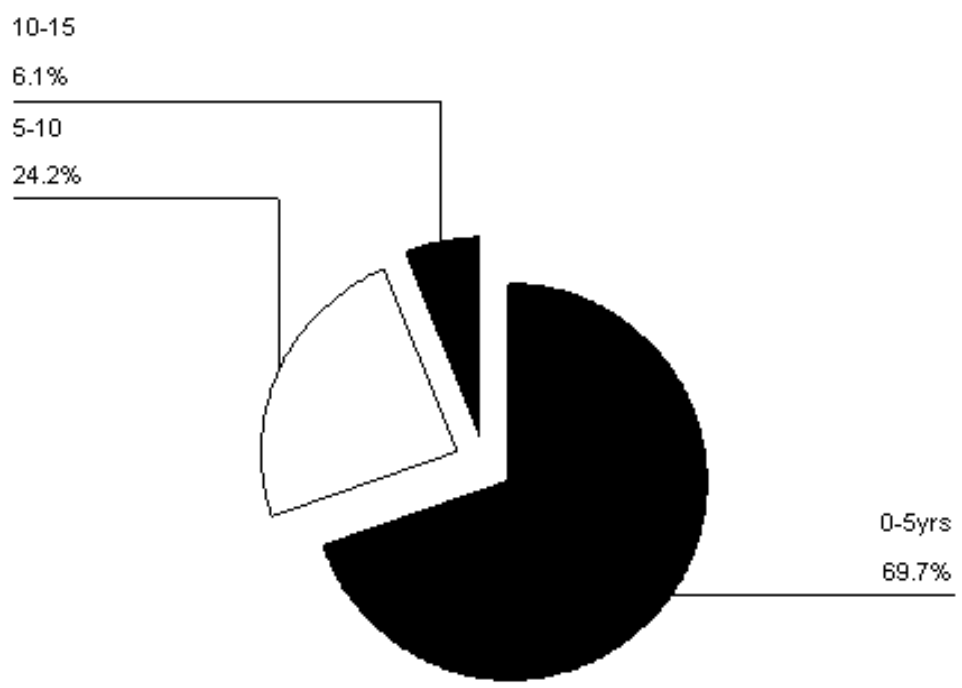

Figure 3. Length of service

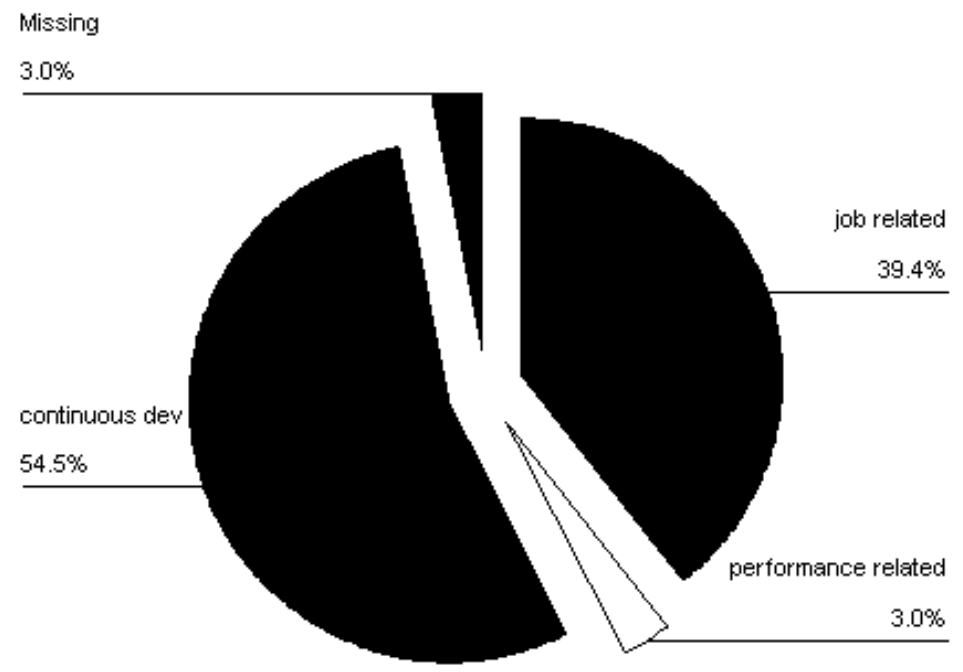

Figure 4. Type of training 


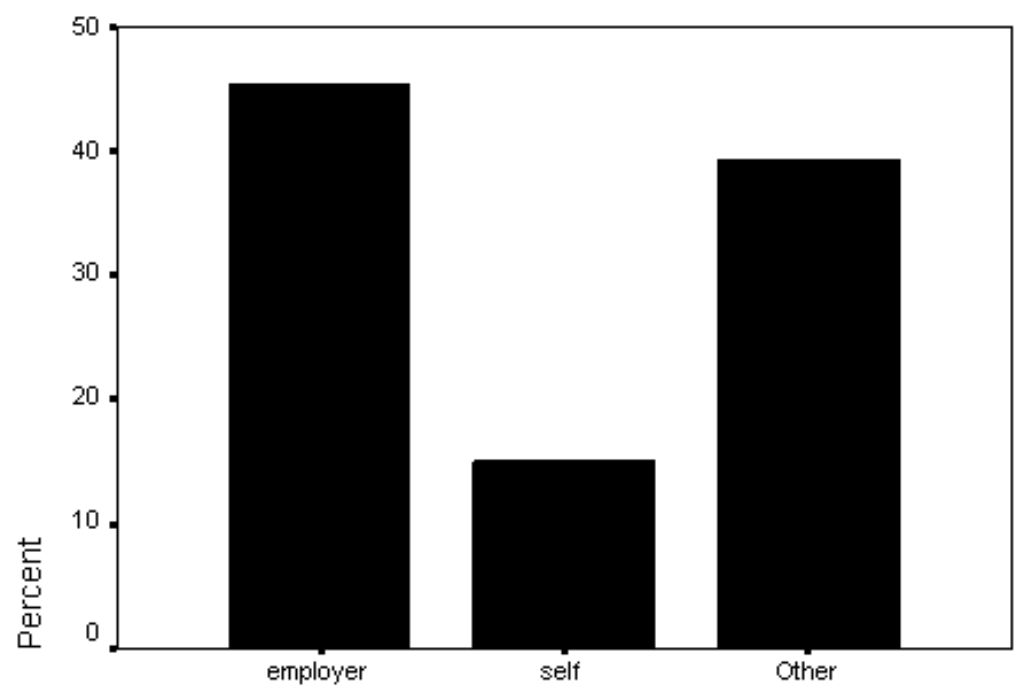

Figure 5. Who paid for the courses

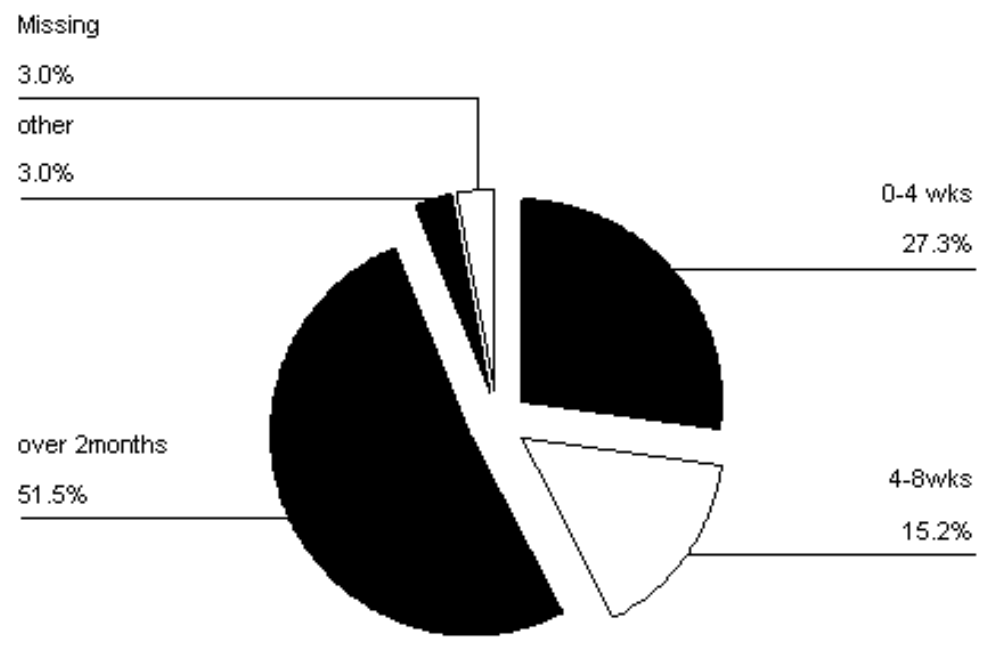

Figure 6. Duration of the course 


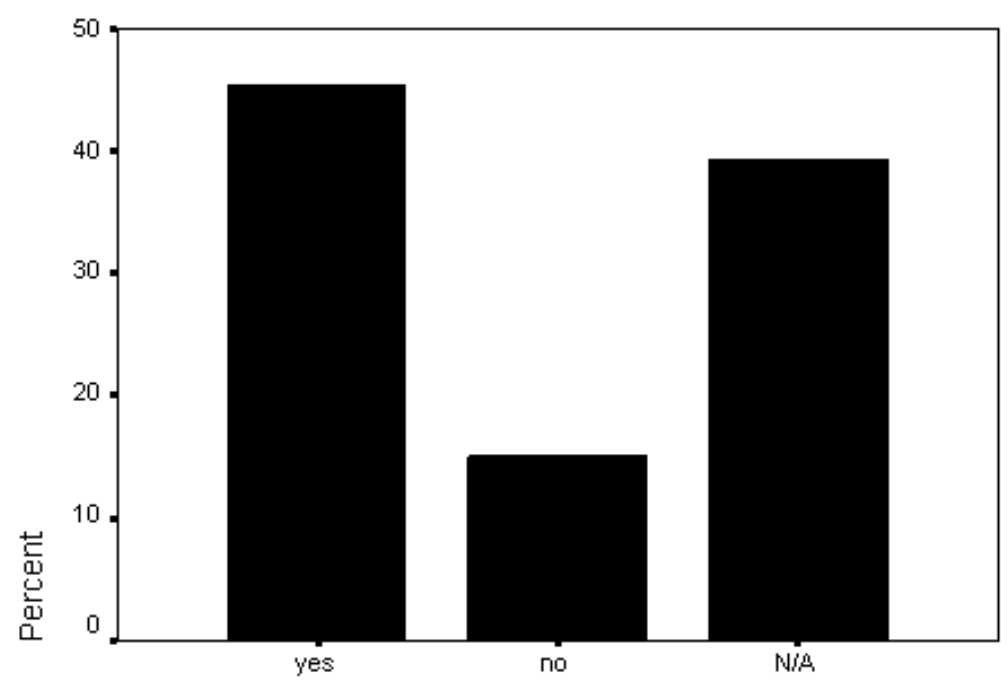

Figure 7 . Was the training related to the work you are doing

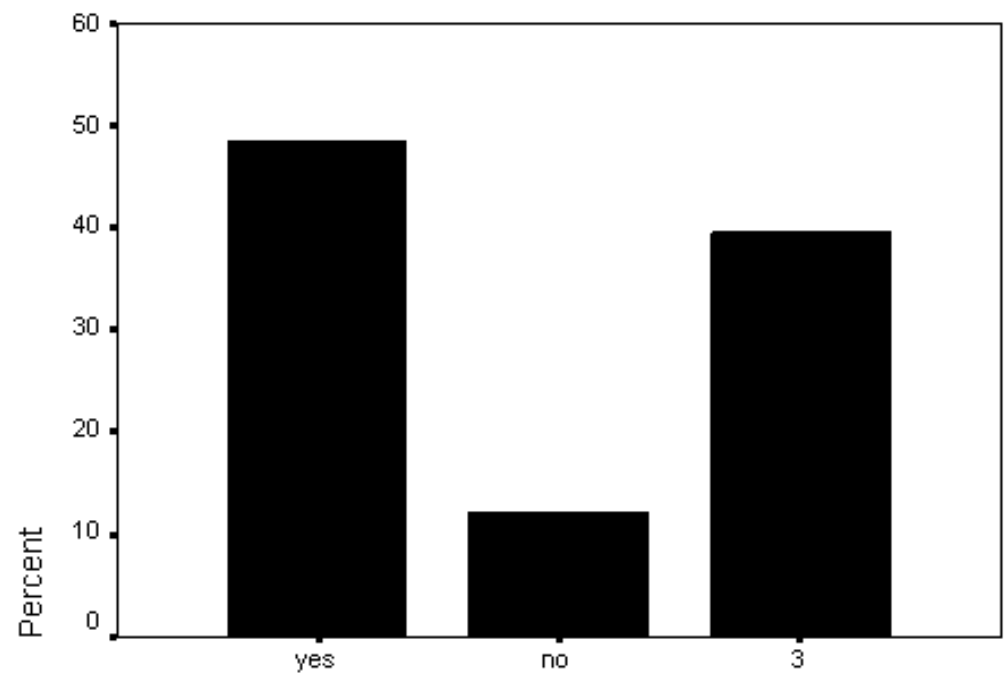

Figure 8. Training useful in helping you perform your tasks better 


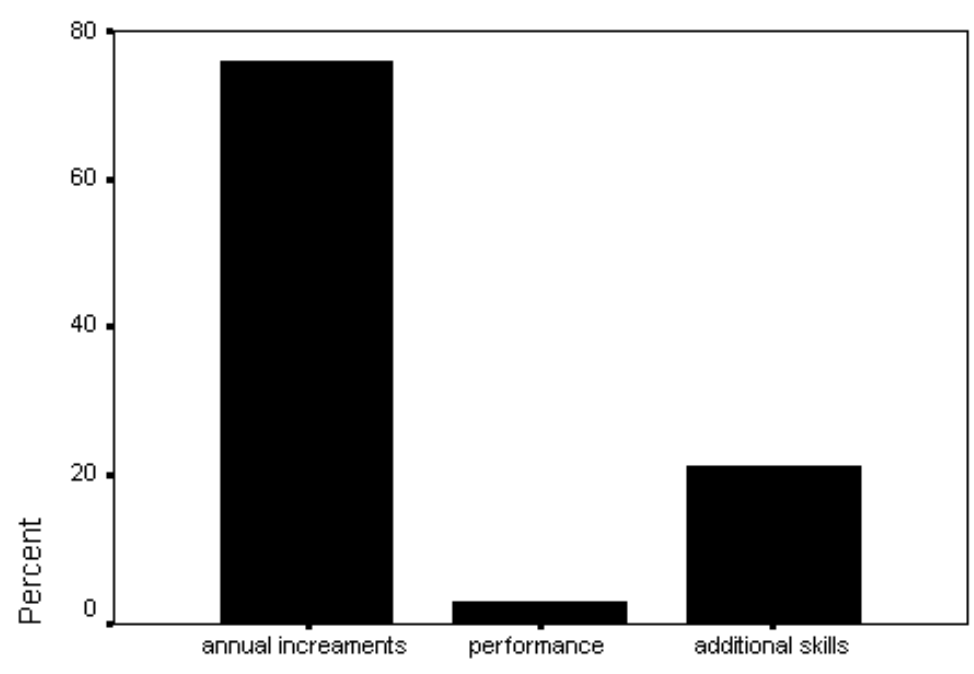

Figure 9. What basis is salary increments affected

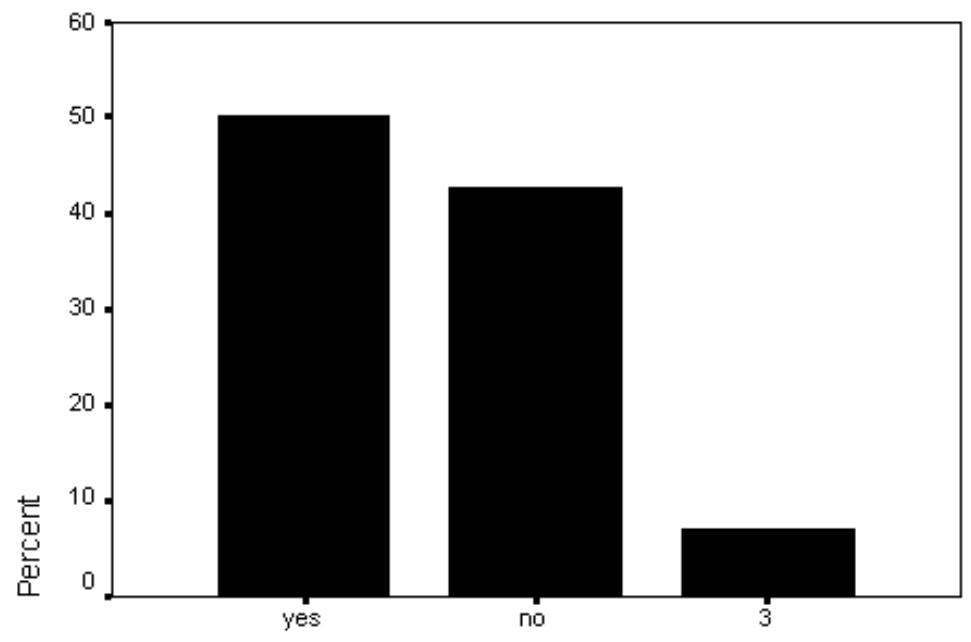

Figure 10. The rewards motivate you to improve performance 


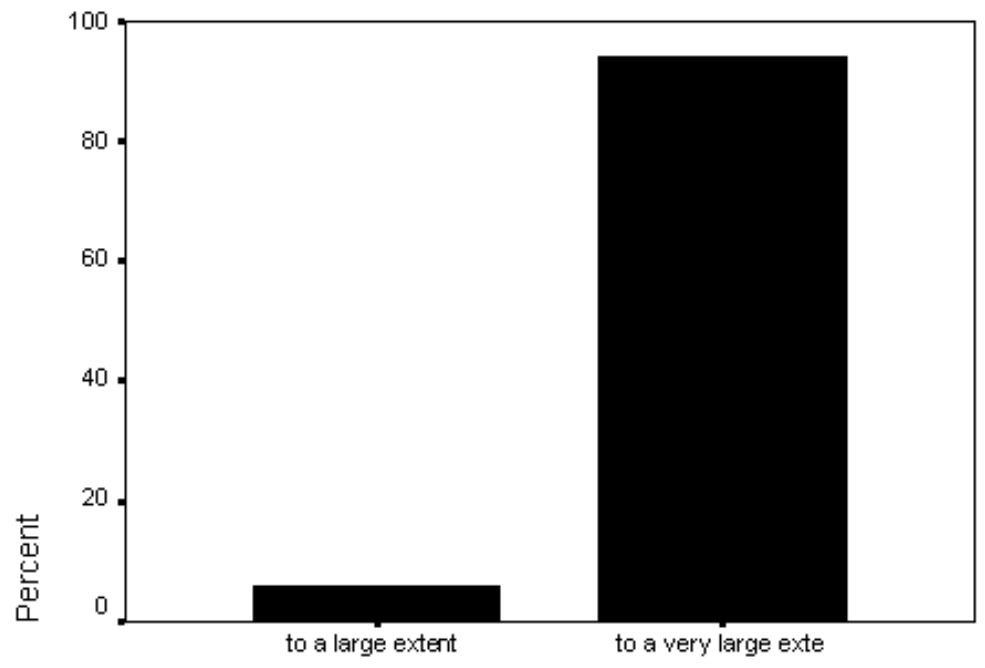

Figure 11. Fair administration of rewards

\section{Appendix}

Questionnaire for Support Staff

1. What is your gender?

Male

Female

2. Highest Education level attained $\mathrm{KCPE} / \mathrm{CPE}$

O - level /A level

Diploma/certificate

Bachelors degree

Masters degree

Other, please specify.

3. For how long have you served in this organization?

$0-5$ yrs

5-10 yrs

10-15 yrs

Over 15 yrs 
4. In what job grade are you?.

5. a) Have you attended any course or training in your present position for the last one year?

Yes No

b) If yes, what type of training?

Job related training

Performance related training

Continuous development

Other, specify

c) Who paid for the course?

Your employer

Self

Other, please specify

d) What was the duration of the course?

0-4 wks

4-8 wks

Over 2 mths

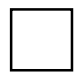

Other.

e) Was the training related to the work you are doing?

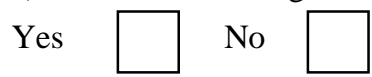

f) Were you consulted or interviewed before the training to identify your weak areas?

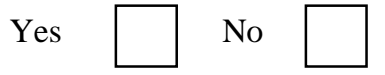

g) Did you find the training useful in helping you perform your tasks better?

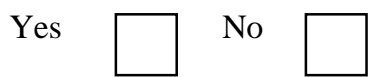

h) Was there a difference in the feedback given to you by your supervisor before and after the training? Yes No 
i) If yes, did the feedback indicate an improvement in performance?

Yes

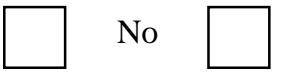

6. What is the basis of rewards in your organization?

Performance

Skills

Competence

Length of service
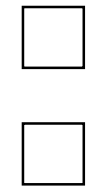

Other

7. On what basis are salary increments effected?

Annual increments

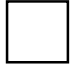

Performance

Additional skills

Other, please specify.

8. Do you perceive fairness in the way salary increments are effected?

Yes

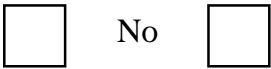

9. a)Does your supervisor clearly define the performance targets that you are expected to achieve?

Yes

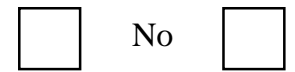

b) If yes, in your opinion are the performance targets achievable?

Yes

No

10. a) Do you receive feedback from your supervisor on how well or poorly you have performed your tasks?

Yes

No

b) If yes, how often is the feedback given?

Every $1 \mathrm{mth}$

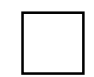


Every 3 mths

Every 6 mths

Annually

Other.

11. a) Do you receive any financial rewards or salary increase following achievement of the set objectives?

Yes

No

b) If yes, do you value the financial rewards or salary increase administered to you?

Yes

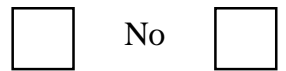

c) Do the rewards motivate you to improve performance so that you can get more rewards?

Yes

No

12. a) Do you think your performance affects the performance of the entire organization?

Yes

No

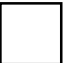

b) If yes, how?

Positively

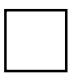

Negatively

Other.

13. What obstacles do you encounter while trying to achieve your performance targets?

14. Give suggestions on how the organization can improve your performance

15. To what extent would the following practices improve your performance? 


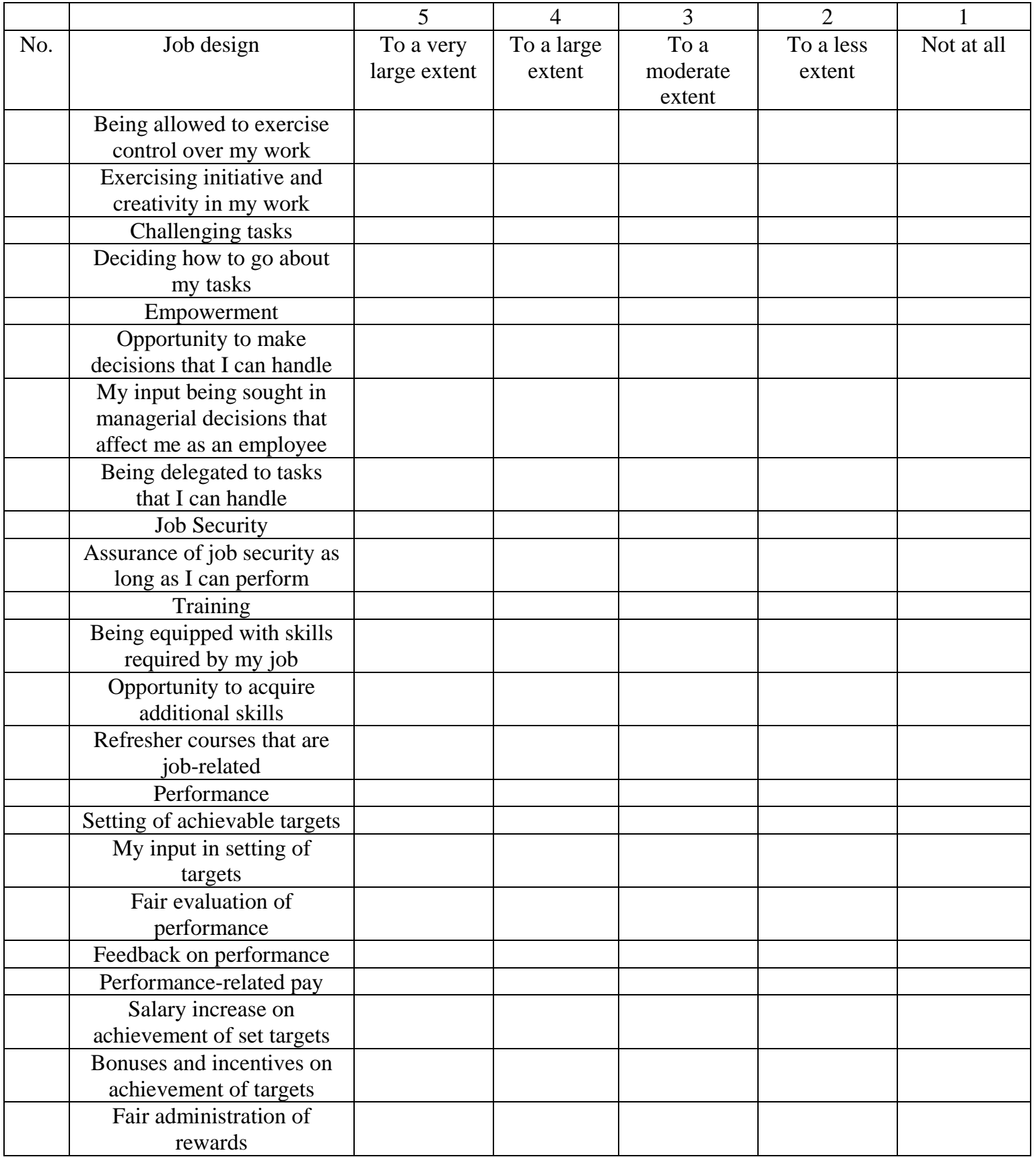

